\title{
ELECTRON MICROSCOPIC STUDIES ON HUMAN TRACHEAL GLANDS
}

\author{
MORITO NAKAYAMA \\ Department of Otolaryngology, School of Medicine, Gunma University, Maebashi \\ (Director: H. Ishii, M.D.) \\ Department of Anatomy, School of Medicine, Gunma University, Maebashi \\ (Director: S. Shibasaki, M.D.)
}

An electron microscopic study on fine structure of the human tracheal glands, on which few reports have been published, was carried out. The materials were obtained during surgical procedures of the larynx and trachea.

The human tracheal gland mainly locates in submucosa of the trachea. The shape of gland is simple or compound tubulo-alveolar, and the gland has a duct and a secretory portion (acinus). The secretory portion of the gland comprise of mucous cells and serous cells consistently in a regular arrangement. The mucous cells adjoin directly distal to the branched duct and followed by serous cells. Serous cells form frequently a demilune. The secretory portion of the gland is surrounded by myoepithelial cells resembling smooth muscle fiber, and they are encased further by membrana propria comprised of a basement membrane and connective tissue.

The duct of the tracheal gland has double layers of epithelial cells, viz. tall columnar cells facing the lumen and basal cells outside. The tall columnar cell frequently contains round granules suggestive of an active secretory function.

In our observation ultrastructural characteristics of the mucous cells and of the serous cells are investigated separately, and the mechanism of secretion is morphologically elucidated through the electron microscopic investigation of their morphological changes corresponding to the secretory cycle. No appreciable morphological difference exists between the serous cells constituting serous tubules and demilune.

Mitochondria-rich cells (oncocytes) are occasionally found within the epithelium of the secretory portion and in a rare instance they contained secretory granules.

Several findings on myoepithelial cells resembling smooth muscle fiber which are found in a considerable number at the base of the glandular cells of the secretory portion are described.

A79-0265. 71010

\section{ヒト気管腺の電子顕微鏡的 研究}

\author{
群馬大学医学部耳率胭搌科学教室（主任：石井英男教授） \\ 群馬大学医学部第一解剖学教室 (指導: 柴睛 晋教授) \\ 中山秲人
}

緒言

ヒトおよび各種学椎動物の気道粘膜の微細桧造に関す

る研究はきわめて多く，枚挙にいとまがないが，中でも
粘膜上皮については光学ならびに電子影微鏡により詳細 な観察がなされている（伊東ら $\left.{ }^{1)}\right)$ 。しかし，気道粘膜 の諸腺組織に関す万報告は比較的少なく, 光学影微鏡に 


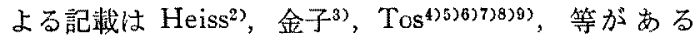
のみである. 近時, 電子顕微鏡観察が広く行なわ机るよ らになつたがやはり気道粘膜の諸腺組織に関与る報告は 少ない，著者は，さきに教室の金子かが行なつたヒトの 気管腺の光学顕微鏡钼察の結果を基礎として, 電子顕微 鏡観察を行ないヒ卜気管腺の微練構造を明らかにしょう とした。な挸腺に関す万岩井 ${ }^{100}$ の光学頙微鏡的硎

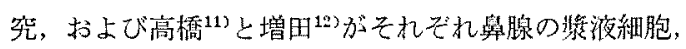
粘液細胞について電子影微鏡を用いて詳細な細胞学的検 索を行なつているので，これらをも参考上してヒトの気 管腺の電子頙微鏡所見について報告寸る。

\section{研究材料と方法}

研究材料は当耳鼻咽唉科泟执いて施行した36才から 74 寸までの男女 23 例の気管切開術または喉頭全摘出術の際 に採取したものを使用した，採取部位忟気管軟骨間部ま たは膜性壁の健常と思われる部位である. 固定液はCaulfield 氏液, Millonig 氏液および cacodylate または phosphate 緩衝 $2.5 \%$ \%゙ルタールアルデヒド液を用い た。採取した組織片は直ちに泠却した固定液中に投入し て約 1 立方粍大の細片とし，さらにオスミウム液では90 分間, グルタールアルデヒド液の場合は 2.5 時間固定を 行ない，水洗後さらにオスミウム混液にて90分後固定を 行なつた，固定完了復こ机らの組織片は水洗することな くただちに湾強エタノール系列にて脱水し、プロピレン オキサイドを通した後，定法に従つてEpoxy Resinに包 埋した (Luft $\left.{ }^{132}\right)$. Porter-Blum MT-I 型ウルトラミクロ トームにより超䔦切片を作製し，酰酸ウラン上鉛（Millonig 氏法の Luft 氏変法) 2 重染色を施し，JEM$100 \mathrm{U}$ 型電子影微鏡にて観察, 写真撮影を行なつた。な 㧍，隣接切片を semi-thinsection としトルイジンブルー にて単染色し電顕所見の参考しして比较検討した。

\section{所見}

1. 気管腺の一般的構造

ヒトの気管腺は篻一または複分岐管状胞状腺で，主に 粘膜下組織内に見出され，分泌部（終末部）は粘液細胞 上嶈液細胞の2 種類からなる泿合腺である。気管腺は骐 性壁においてもつとも大なる腺塊を形成しており，気管 㳄骨部では比較的小さいものが多く軟骨閒部では再者の 中間である.腺は導管を経て上皮に開口する。この腺の開 口部において，上皮部すなわち杯細胞を混ずる多列瀻毛 上皮浪陷凹を示す，宿凹は浅い杯状を呈するものから管 状の梁いるのまで敇なあり，上皮の性状は粘膜表面上皮 と同じく，光影的基底膜を伴な5多列繊毛上皮である。
導管注比較的広い内腔をもち，その長さは区々で個々の 腺により，またその存在部位によつてことなる，軟骨部 にみられ，比較的浅部にある腺では尊管は短かく，走行 も单純で著明な彎曲を示さないが，腾性壁で梁部にある 腺では導管は長く, 屈曲を示し, 上皮陥凹に開口寸る. 導 管上皮は，高円柱上皮細胞と，これの基底部にならふ類 円形の基底細胞とからなる2列上皮でこの外側面は終末 部加ら連続する固有膜（基底膜と結合組織とからなる） によつて包まれている（附図 1)，導管はときに分䁌を示 すことがある、導管につぶけて終末部 (分泌部)がある。 終末部恃複雑に分岐することが多く、管状胞状腺の形態 を示す。すな⿰力口，切片上，弱拡大写真 (附図 2，3)で 観察すると，終末部は円形，楕円形，管状等種々の断面 を呈する。終末部を構成する腺細胞は腺腔を囲んで 1 層 に並び円柱形で，ここには粘液細胞と將液細胞とがあり 混合腺である。両者の微絧構造等については後に詳述す るが，すでに光顕観察によつて明らかにされているごと く, 雨種腺細胞の分布状態には一定の規則性がみられ, 導管に続いて粘淮細胞が並ぶ粘液性終末部があり, それ の末端側に浆液性終末部があるがしばしばいわゆる半月 (demilune, Halbmond) を形成している. 終末部は導管 と同様にその外面は固有膜によって取り囲まれるが，腺

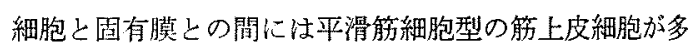
数存在する。気管腺の一般的形態は上記の如くである. 終末部を構成する腺細胞は, 前述のごとく粘液細胞と獎 液細胞との 2 種からなる。雨種腺細胞の鑑別は充盈期で 分泌顆粒が紏胞内に充満している時期には容易である が，分泌顆粒の少ない補充期初期（空虚な時期）などで 岋その判別はなかなか困難である、しかし，すでに述べ たごとき両種腺細胞の配列の規則性や弱扡大写真による 広視野像の観察, 準超薄切片を作製して隣接切片対称法 を行なうこと等により雨種腺細胞の判別は不可能ではな い. 以下腺細胞についてその所見を述べる.

2. 粘液細胞の微細構造

粘液細胞は導管につつくく終末部のもつとも開口部に近 々部分に位置して見出され，粘液緗胞のみからなるいわ 少る粘液管を形成している，比校的広い内腔在目九で高 円柱形の粘液細胞が一層に並び，管はしばしば分岐する のがみられる。本研究に使用した例では充盈期の細胞が 多く，他の分泌周期のものは少ないが，これらの細胞は 充盈期のものと混在してみられ，隣接する細胞が必ずし む同一の分泌周期を示すとは限らない．ここでをず，本 細胞の概形ならびに細胞内にみられる核, 細胞小器官等 
の微細構造について一般的に述心゙る。

i) 核

本紐胞の核は，分泌周期によりその形態と位置に著明 な変化がみられる。いわゆる機能休止期または補充期の 初期で細胞内に少数の分泌顆粒をもつ細胞では, 核は細 胞のほぼ中央か，やや基底部に偏つて存在する（附図 4，5，6）。外形は長棈円形ないし卵円形の断面走示し，

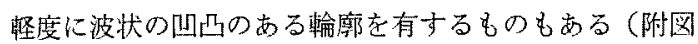
4，5，6）。核犋は微練顆粒状であるが，暗調な異犋染色 啠 (heterochromatin) は樛膜の内側に沿ら部分と，核 内では不規則な小斑紋をなしてみられる。核小体は通常 核の深部にみられ，核膜に接しているものは少ない（附 図 5). 高密度球形の小体として見出され，核小体系 (nucleolonema）はあまり明瞭ではなく，しばしば異質染色 質がこれに接して存在するのが認められる．分泌顆粒が 增加するにつ机て，核は次第に紐胞基底部に向つて位置 を変ずる（附図 $2 ， 5 ， 7 ， 8$ ）。核喟付渐次高密度となり， 輪廓の凸凸も著しく，ときに深い切れこみをもつものも みられる。にくに核の上面で核上部の分泌顆粒に接する 部位には顆粒による圧痕がしばしば胃出される（附図7， 8). また核内に微紐顆粒と微細線維とからなる複合体 でいかゆる spheridion" 上呼ばれる棈造在認めること がある(附図 5)。

ii) Golgi 装置

本細胞の Golgi 装置は核上部にあり，分泌周期に応 して著明な形態変化を示す。機能休止期ないし顆粒形成 初期には，Golgi 装置の発達は不良で，構造も簡単なも のが多いが（附図 4，6），補充期から充盈期にかけて著 しく溌達し，形成された分泌顆粒の閒心長い迁曲寸る索 状をなして認められる（附図 5，9）。 Golgi 装置泟初期 には核上部で，少数の Golgi 層板と Golgi 小胞とから なり細胞質の小野を取り囲んで配列し，いからる Golgi 野在形成している(附图10)，分必顆粒は初为このGolgi 野内に出現し，数を增すとともに增大寸る。Ｇolgi 装置 も扁平りう状の Golgi 虽板上 Golgi 小胞の他に Golgi 架胞もみられるょうになり，上くにGolgi 尿板の発陸 は著明となる（附図 5，9）。このため Golgi 野法搪大 し，核上部のかなり広い部分を占めるようになり，その 周囲には采粒体や内腔のやや昖大した粗面小胞体がかな り多く分布寸るのが認めら机る（附図 5，8，9）。これ が光顕的に中間暗带と呼ばれる部位に相当する電顕所見 である(附図 5，8，9）。分泌顆粒は集団をなし核上 部がら細胞先端部にかけて分布するが，上述の中間暗帯
により模上部で核に接近してある集団と，細胞先端部で 腺腔面絊胞膜（形澌膜）直下にある集団とに別れ，その

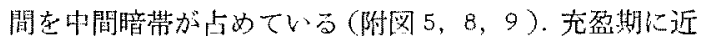
ふくにつれて，顆粒は増加し，中䦤暗带は狭くなる。 Golgi 装置は層板がとくに発達し数個の扇平のらが長く 迂曲し，核上部でU字状を呈するものや蛇行するものが 認められこれらが分泌顆粒の間に見出される（附図 5 ， 10). 充泵期加ら排出期にか子ては核上部はほとんど顆 粒のみで占められるようになり，Golgi 装置やその他の 細胞小器官は見出し難くなる(附図8)。

iii) 采粒体

本細胞の糸粒体は分泌周期を通じて細胞内全域に散在 性に見出されるが，上くに核周囲の細胞翼層に多く分布 している（附図 4，5，6，7）。長杆状，棈円形を示与も のが多く，限界膜の2 重構造注明膫で，系粒体稜は櫛状 に证列する paired membranes で比較的疎にみられ， 米粒体内顆粒沙ない，基煌は中等電子密度であるが， ときに膨化傾向を示し低下することがある（附圆11）。 補充期には核上部の Golgi 装置の周囲，上くに Golgi 野内に多数認められるようになり，分泌顆粒に密接して いるものもある(附図 5，9，11)。形は長杆状のものも 从られるが，冈形の断面走示すものが多い．核上部に分 泌顆粒が增加寸るにつれて, 釆粒体は他の細胞小器官上 同様に，顆粒の間にこれと混在するようになるが，さら に顆粒が增加して充盈期に到るとほと儿ど認妙られなく なる（附図 2，8，10）。一方，核周囲部のものも，この 㭙期になると核の紐胞基底部一の移動，核周囲の原形澌 層の減少に伴ない，ほとんど見出されないままた，補充 期の細胞について，分泌顆粒形成々系粒体との関連につ いて詳細に娭妻したが，系粒体が分泌顆粒と密接する像 はしばしばみられたが、これが直接分泌顆粒に転化する ことを示唆する所見は認められなかった。この㭙期の采 粒体は膨化傾向在示し, 基翼の電子密度が低く, 米粒体

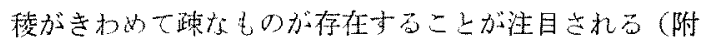
圆11).

iv) 粗面小胞体:

粘液細胞内に滑面小胞体はほ上んど見出さ机ないが， 粗面小胞体はかなり存在する. 分泌周期の時期の推移に したがつて記戴すれば次のごとくである。、わゆる機能 休止期ないし補充期の初期にかけては，辟平の5状の粗 面小胞体が核周图部，および核上部の Golgi 野内考除 く細胞全城に分猚するのがみられ，これらは比較的蹯な 層板快配列示している（附图 4，8，9），外表面汪り 
ボゾームの付福する限界膜で围まれ，内腔の䉓子密度は 細胞基質とほぼ同憡，中等電子密度で，均質性である。 柇着リボゾーム (attached ribosomes) の分布状態はかな り緻密で特殊な配列状態を寺さずほほ均等に分有してい 万(附図 12)，粗面小胞体は補充期に分泌顆粒が堌加す るにつれ，それらの閒に䇲独または少数の集団をなして 混在するが，多くは扇平のら状を呈し，系粘体に密接す るむのや，こ机取りまくよらに配列するものがある （附図 9，12）。しかし不規則な膨隆や空胞状を品する ものはほとルど見出されず，内腔の電子密度が增大する 所見もない，Golgi 層板に沿つてしばしば自由なリボジ 一ムの集団も存在方ることが注目される（附図11）。犯 盈期には長い菜状の Golgi 層板の周国や，わずかにみ られる顆精閐の細胞質内にみられるが一般に細胞質が竟 電子密度となるため不明瞭となる。上述のごとく，粘液 細胞に叔いては，粗面小胞体注機能休止期ないし補充期 初期に结，核周囲部队核上部に扁平のうの集団としてみ られるが，時期が進むにつれて分布は柾上なり見出し奞 くなる。このように分泌周期安通じて粗面小胞体の增減 が認められ，采粒体やGolgi 装置と密接な位置的関係 をもつことも明ら就となた。

v) 分泌顆粒

粘液細胞の分淡顆粒は初め核上部の Golgi 装置の周 里または Golgi 照内に出現する（附図9，10）。なな

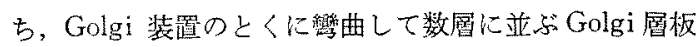
の凹面側に Golgi 架胞に混在して滑面限界膜に包まれ,

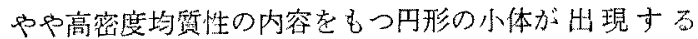
（附図 9，10）。この付近には粗面小胞体，系粒体，自 由なリボゾームが存在し，小体は次第にその数と大きさ をまして分泌顆粒しなり，集団として核上部に並ぶが， 一部は腺腔面細胞膜直下にも第団上なつて見出されるよ 5 になる（拊図 8，9）。補立期に怙られる分泌顆粒の大 きさは充㿽期のものに比して小さい居のが多く，個々の 顆粒で篦子密度に若干の相異があり，とくに Golgi 野 内の小さいので注密度のむのがある（附図9）。 ま

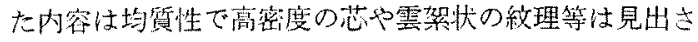
れない（附図 7，8）。充盈期になると，顆粒は一般に大 きさをまし細胞をみたすが，この㭙期にはかえつて顆䊀 は低密度となり空胞状となる（附図 2，8）。この際に大 なる分泌顆粒の周辺部が明るい露をるち，中央部に輸廍 不明膫な円形の芯をむつものがみられることがある（附 図13，14）。しかし，排出期のものではこのよらな所見 は認められない。この㭙期には顆粒のゆ合像がかなりみ
られるよ5になる（附図15，16）。分泌顆粒形成機序に ついては，すでに各項において㲔述したごとく，Golgi 装置，粗面小胞体およぴ系粒体は密接な位置関係を示す ことが明らかで，とくに Golgi 野内に扎いて Golgi 小 胞, Golgi 空胞と小さい分泌顆粒との移行像が認めら れ，これら細胞小器官の協関によつて可視的顆粒になる と考えられる。

vi）その他の㯍造

i ）加 $5 \mathrm{v}$ ）に执いて述心たものの他に，本絊胞内に は脂翼滴（附図 4)，ライソゾームと考えられる高密度 小体（附図 2,4，5，6，8），微細線維束（附図 4) 等 がしばしば認められる。これらはいずれも分泌顆粒をほ とんど持たないか，または少数もつ細胞に出現すること が多い，高密度小体は円形，楕円形ないし不規則な凹円 をもつもの等種々のものがみられ，内部の電子密度が均 一なものか゚多いが，ときに高密度の内容の一部に明るい 空胞を含むものもある。これらの高密度小体は補充期な いし灰怒期には，核上部から細胞先端部にかけて存在す 万分泌顆粒の間に混在している。微細線維束は細胞によ り含まれる量はきわめてことなるが，多く含まれる場合 注核周囲の粗面小胞体の間や，核上部で小野を形成して 見出される。

3. 粘液細胞の分泌周期に応ずる形態変化

気道粘膜の諸腺組織を観察した報告のなかでヒト気管 腺を光影的に観察した金子"3（は分泌周期を機能休止期， 補充期，充盈期，排出期の4期に区分して記載している，

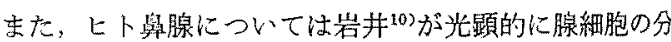
泌周期をやはり 4 期に分けて述心゙ている。一方，七卜悬 腺を電顥的に観察し，それぞれ獎液細胞(高橋11)，粘液 細胞（增田 ${ }^{12)}$ ) について分泌周期に応じた各期の微細構 造党記載した報告があるが，彼等は分泌周期をさらにく わしく区分し浆液細胞については6期に，粘液細胞につ いては8期に分けている。著者は基本的には金子"3の区 分にしたがつて述へるが，機能休止期の分泌顆粒のない 㤎虚な細胞にはほ上儿上造遇しないのでむしろ補充期初 期として記截寸ることが邀当であると考える。

1) 補光期初期（機能你上期）(附図4，5，6）

多数の切片について観繁を行なつたが，光影観察でよ くいわれるいわゆる機能休止期，分泌顆粒のみられない 然虚な縕胞を見出すことはほとんどなく，電影切片ては 必ず少数ではあるが小さい分泌顆粒が見出される。この

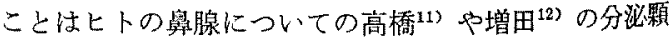
粒出現の極初期の所見に相当し，光影的な休止期はむ 
しろこの時期に相当するものと考えられ，分泌顆粒形成 が休止することは機能発現中の緗胞では全くないか，あ つてもきわめて短時間であることが推察される．この時 期の細胞は後述するごとき明調で大なる粘液顆粒を多数 含む細胞の間にこれと混在してごく少数見出される．こ の細胞は他の時期の細胞に比べてやや小さく，高さむ低 い. 核は胞体の中央部か, やや基底部に㑤在してみら れ，多くは棈円形であるが小さい陷凹や波状の輪廓を示 すものもある。異澌染色翼は小さい集塊を作り，核膜に 沿ってみられるほか核内に不規則に分布している。核小 体，spheridion がときに見出される(附図 5 )。細胞澌 内には練胞小器官は乏しいが, 微細線維状構造が, 上く に核上部に豊富に含ま机ることが注目される。このこと は竹液細胞においてては認め難い所見である。核側部から 核下部には扁平のう状の粗面小胞体が㻋に層板状に並 び，長杆状ないし榜円形の采粒体が少数混在している。 Golgi 装圆は核上部で核に近接して見出されるが，各要 素の発達は余り著明でなく, 少数の Golgi 層板とその周 囲にGolgi 小胞の小集団がみられるのみである。核上部 にも禾粒体上扁平のう状の粗面小胞体が島燃状に微細線 維束の間に見出される。分泌顆粒は小さい円形の断面を 示す小体としてみられ，滑面限界膜に包未机やや高密度 て均質性の内容をもち，一般に細胞先端部に小集団とし て存在する。限界膜に沿つて不規則な高密度の縁 (dense rim）をもつことがしばしば観察される。このほか核 上部にはポリゾーム，微細な不規則形の高密度小体がか なり多く認められ，後者は小分泌顆粒集団の間や Golgi 装置に近接して存在する傾向をもつ。この時期の細胞で とくに注目されるのは大なる脂質滴をるることである。 この脂質滴は核周囲部に多く，そのためときに核に大な る圧痕を生ずることもある（附図 4)，腺腔面細胞膜は ほぼ平坦で短か、微紋毛が柾に派生している。隣接細胞 と接する側面も一般に平坦であるが，ときに簡単な細胞 間既合をみる。腺腔端に注 junctional complex の形成 があり，媣部には desmosome が所々に見出される、基 底面は筋上皮細胞と接する部位では比較的平坦な面で接 しているが，筋上皮細胞間で直接固有膜に面する部位で は著明な凹凸を示すことが多い，

2) 補充期 (附図 5，7，8，9，11，12）

この時期には分泌顆粒は逐次数を增し, 紐胞の高さや 大きさも增加する。このような所見を示す細胞は多数観 察され, 種々の段階に分けられる. 分泌顆粒を少数もつ 湅胞では, 各種細胞小器官の発㙂增数がみられ細胞はや
や隌調を呈する（附図 5，8，9）．とくに核上部の Golgi 装置は藷しく発韭し，小さい分泌顆粒を含む大きな Golgi 野を形成するようになる(附図 5，9). Golgi 小胞は かなり増加し，小さい分泌顆粒と混在している。 Golgi 野の周囲に注主に形ないし棛円形の系粒体が Golgi 野 をとりかこむように配列しその数もかなり多い，粗面小 胞体も增量している。ここにみら机る小分泌顆粒の電子 密度には相異がある。橫には渚しい形態の変化は見出さ れない，補充期が進むにつれて分泌顆粒は增加し，さら にその大きさも增す。しかし，顆粒の電子密度は充盈期 のものに比して高いものが多い。これらの分泌顆粒は核 上部でしばしば集団をなしているがその分布状態には特 徵がある。まず，核上部で核に近接してみられる分泌顆 粒集団が索る，比較的早期のものではここに，小さい分 泌顆粒が Golgi 装置にとりかこまれるように㻋に配列 してみられるが，溷次をの大きさ定しし，顆粒相互が密 に接するようになる。.Golgi装置もますます著明となり。 よく発達した Golgi 層板が罢い彎曲を示して諗如れ， 核上部の分泌顆粒集団を上方 (腺腔側) から包むように 唒列する。このほか粘液細胞の先端部で，腺腔面細胞膜 直下に集合する分泌顆粒集団がみられる。この2つの分 泌顆粒集団々りまいて, 采粒体, 扁平のら状の粗面小 胞体，自由なりボゾーム (polysome)がみられるほが初 期には微細線維状構造がかなり多く存在するが時期が進 むにつれて減少する。束た金于 ${ }^{32}$ は上卜気管腺粘液細胞 の光就観察に㧍いて補充期に核上部之細胞先端部の粘液 顆粘集団の間に暗調な原形犋瘜が見出され，横地153が十 二指晹腺細胞に喼めた中間暗带に相当することを報告し ている，そしてここにKolatchev 氏法により黒化する 網を形成する Golgi 装瑥のあることを証明している。本 観察においても，補充期にいわゆる中閒暗带に相当する 原形質層が認められた（附図 5，8，9）。電顕観察によれ ばこの暗帯に一致して金子3) が指摘したごとく，Golgi 装置が認められるとともに，層板状配列を示す粗面小胞 体, 綵粒体、ライソゾームと思加机高密度顆粒が存在 する。この中間暗帯は顆粒が増加し，その大きさをます につれて狭小となり, 発達し迁曲する Golgi 層板が顆 粒に混在して認めら机るのみとなり，他の小器官は細 胞周辺部に圧排される。核上部において上述のごとき変 化が進さにつれて核は次第に細胞基底部に向つて圧迫さ れ位置を変ずる，核質は渐次高密度となり輪謜も不正で ときに樑い切れ込みをむつものもみられる。核周囲にみ られた采粒体や粗面小胞体仕さらにわすがなり，脂質 
滴も見出し難くなる、補充期を通じて沙若な分泌顆粒は Golgi 装置の周囲上くに Golgi 野内に多くみられる（附 図9). Golgi 装置ではとくに Golgi 層板が索状に数層互 に密接して並び，それに接して少数の Golgi空胞と Golgi 小胞上がみられる。このような Golgi 装置が核上部で 細胞質の一部をとり囲むごとく立び Golgi 野を形成す るがここにみられる幼若な分泌顆粒はしばしば不規則 形で内容もやや粗鈢である。充盈期に近くなると核上部 の粘液顆粒注互に密接するようになり，顆粒をいくつ加 の集団に分けるように強く迂曲した Golgi 層板が介在 する (附図 5). 他の細胞小器官はわずかに顆粒間に見 出されるのみとなり，細胞犋は周辺部に圧排される。

3) 充盈期（附図 $2 ， 5 ， 8 ， 13 ， 14$ )

粘液細胞が分泌顆粒で充満すると，核はさらに緗胞基 底部に圧迫されほとんど基底面細胞慕に接ずるようにな り，両者の間には狭い原形鲑層がわずかにみられるのみ となる。元蔽する粘液顆粒のため核にはしばしば圧痕方 生じ輪碚は多くの凹凸をもつ不正形となり模質も暗調上 なる，核上部の分泌顆粒は数をますとともに大きさも堌 し，ほとんど核を除く細胞質全域を占めるようになる。 補充期には分泌顆粒の大きさにも大小不同性がみられ， 電子密度む顆粒によつてことなることがあるが，光盕期 になると，一般に大なる顆粒が多くなるが，電子密度は 低いものが多く，明るい均翼性の内容をもつようにな る. 明調な顆粒は互に密接して並び，その間にほとんど 細胞暨層がみられず，互に限界膜をもつて直接接するこ とが多、：しかし限界膜に交通が生し内容がゆ台する傾 向はわずかに認められるのみである。細胞質は一般に高 電子密度となり内部の檴造を見出すことはなかなか困難 である。しかし，核上部の分泌顆粒集団の間にわずかに 島脿状に認められる細胞質の中には少数の采粒体, Golgi 装置をることができる、脂所滴はほとんど見出さ れないこの時期に細胞は最も高さを增し, 横径も大と なり，しばしばビール楻状を呈するのが認められる。腺 腔面の微羢毛は蹯で短小なものが多いが，派生する密度 は細胞によりかなりの変動がある。

4) 排出期（附図15，16）

細胞内に分泌顆粒が立渵する充骓期をすぎる上顆粒排 出期に入る．粘液細胞の腺腔面は腔に向つてやや膨隆 し，表面に派生する微綫毛江数も減少し，短小上なり， 膨隆の著るしい場合にはほとんど消失することもある。 核上部に集積する明調な分泌顆粒が相互にゅ合すると思 われる所見がしばしば見出されるよらになる。補充期、
充盈期を通じて粘液紐胞の腺腔面細胞膜直下には均質性 無棒造の外形啠層とも呼ぶぶき薄層が存在し，通常細胞 先端部に分泌顆粒が多数集積してもこの層は明睹にみら れ，分泌顆粒が表面細胞膜に直接接していることはな いしかし排出期になると腺腔面細胞膜は深部からの分 泌顆粒の圧道による隆起が生じ，初期には外形質層があ り顆粒は細胞膜と密接していないが，時期が進むにつれ て外形質層は消失し，画者の膜は密接ゆ合するに至る。 ついでそこに小孔が生して顆粒の内容は腺腔内に排出さ れる。この場合粼接する顆粒相互間にしばしばゅ合す る像が認められるので，おそらく細胞先端部の顆粒は emiocytosis, eruptocrine secretion の機構により内容を 腺腔に排出し, 深部のむのはつぎつぎにこの顆粒と接着 ゆ合することにより腺腔と連絡が生じ内容を排出するも の上考えられる．腺腔面が多数の分泌顆粒とともに丘 状，または舌状に隆起している場合もしばしばみられる が, 、わ肪る apocrine secretion の機序を示唆する所 見は見出しえなかつた．本研究に使用した材料はすべて 手術時 (全身麻酶下) に採取したものであるが，排出期 の細胞仙比較的少なく，見出すのはなかなか困難であつ た.

\section{4. 浆液細胞の微細構造}

蒋㳸細胞は終末部の嶈液性腺管および粘波管の末端部 で半月部を形成してみられる，比較的狭い腺腔を囲み細 胞が一屠に配列してみられ，その基底部に平滑筋型の筋 上皮細胞があり，終末部全体は薄い基底膜によつて囲ま れ，結合組織層とへだてられることは粘液部と同じであ る(附図3，17)，細胞間には時に腔面に少数の微諓毛を そなえた細い細胞間細管と思われる構造がみられること がある。また隣接細胞間に微絊毛様の突起をもつ膑隙を みることがあるが，これは細胞間嵌合により接する部位 で細胞間隙がやや拉張して生じたと考えられるるので細 胞間細管とは区別すべきものである，腺管または半月を 形成する浆液細胞は, 後述するごとき分泌周期を示す が，個々の細胞によりその分泌周期の位相は区々で，同 一腺管, 同一半月に拉いて隣接する細胞でも，その周期 は必ずしも同一ではない。

i) 核

浆液細胞の核は一般に細胞のほぼ中央か, やや基底部 に偏つてみられ（附図3，17，18，19）, 分泌顆粒が大量 に胞体内に蓄䆊する充盈期に抦いても核が細胞基底部に 压迫され，変形するよ5なこと注認められない(附図 24）、输漷はほぼ円形ないし棈円形のものから，凹凸の 
ある不規則形を呈するものまで種々である（附図19）。 核質は概して明調で，異質染色翼 (heterochromatin) は 粘液細胞に比して少ないものが多く，主に核膜に沿って 見出されるが，核内では不規則な斑紋状を呈し散在性に 存在する。核小体も高密度微細顆粒の球状集団としてみ られるが，核小体系は余り明瞭でないものが多い，核膜 の 2 重構造は明膫で外膜にリボゾームの付着がみられる が，その分布は不均等である。分泌䪵粒が增加すると， 核は基底側に压迫されるが，極度に变形することはな 、また核内に同心円状に配列する微紐線維と高密度微 細顆粒との複合したいかゆる spheridion (nuclear body) をもつものもある(附図3，17)。

ii) Golgi 装置

Golgi 装置は一般に核上部にあり，比較的広い細胞䝷 をとり围み，いわ的る Golgi 野を形成して見出される （附図20）。槳液緗胞に扮いては，上くに Golgi 空胞上 粘液細胞ほどではないが内腔が連珠状に应大している Golgi 層板の発達が顕著で, それらの周囲に Golgi 小胞 (顆粒) が散在性に存在している.Golgi 装置の周囲に は小胞体, 米粒体, 分泌顆粒等がみられるが, とくに Golgi 野内では，小さい円形ないし棈円形の幼若な分泌 顆粒と思われる構造が常に見出され，これと Golgi 空 胞上の間には明らかに形態学的移行像認める(附図18, 20，21，22）.すな⿰力 Golgi 層板に接して存在する Golgi 空胞には内腔の電子密度の低いものもあるが, 長 棈円形から次第に内容索增し，大きくなり，輪敦も球形 となるにしたがい, 内部の電子密度も増加し, 周用にみ られる小分泌顆粒上区別しがたい良く似た性状を示寸も のまで種々のものが認められる。しかし充盈期に多くみ られる顆粒の内容が比較的均質微細であるのに対し, こ れらはやや粗鈢な内容をもつことが注目される。墏液顆 粒は増加するにつれて細胞の核上部から腺腟面にかけて 次第に蓄積するが，これにつれて Golgi 装置はやや核 上部に圧迫され，核に近接してみられるようになるが， Golgi 層板, Golgi 空胞はよく保たれ，顆粒の間に介在 する小野を形成して認められる(附図23，24）。墏液細 胞においては中間暗帯に相当する構造はみられない。

iii）系粒体

獎液細胞は分必周期を通じてかなり広い原形質野をむ ち、ここに各種の細胞小器官を見出すことができる、本 細胞の采粒体は細胞全域にわたつて広く分布するが，上 くに核周囲部に豊富にみられる粗面小胞体の間や Golgi 装置の周囲に多く存在する（附図18，22，23）。主に円
形ないし棈门形のものが多く, 長忓状のものは比較的少 ない，しかし，形ないし棈円形の釆粒体では外膜の2 重蒘造は明檫であるが, cristae が少ないか，ほとんど 認められないものもあり，米粒体の横断像を示寸所見と も考えら机る，長杆状のもので锥察すると， cristae の 配列はあまり密でなく， paired membrane で，基澌内 の来粒体内顆粒も少ない. 補充期の細胞で钲察すると, 核上部の Golgi 野内に及られる多くの幼若な分泌顆粒 上混在してかなり多くの糸粒体があり，乙代しば雨者が 密接している所見がある（附図18，21，22，23）。補充 期がすすみ充惩期に近くなり核上部のほぼ全域が分跳顆 粒で占められるようになると米粒体は分泌顆粒の閒に散 在性に見出されるが（附図21，24），全時期を通して禾 粒体が直接分泌顆粒に睆化することを示惨する所見は認 めら机ない。

iv）粗面小胞体

本細胞内には全分泌周期を通じてかなり多くの粗面小 胞体が含まれ，常に細胞犋の広い部分庄占めて認められ る. 分泌顆粒が少ない機能休止期ないし補宎期初期の細 胞では，榜上部の Golgi 野を除いてほぼ細胞質全域に 広く分布している（附図18，19，22）。核周囲部で注扁 平のう状を呈するるのが集団上なり小野を形成してみら れ，そこに系粒体が混在している。京た粗面小胞体の集 団の間に溦細線維束のみられることもある（附図18， $19 ， 20 ， 23)$. 核上部で Golgi 野の周团に古るものは扁 平の5状のむのもみられるが，小空胞状を呈するものも ありそれらは free ribosomes 上混在していることが多 い(附図19)。一般に核上部においては粗面小胞体の配 列は核周图部よりむ踈であり，扇平のらや空胞は互いに 訪篗開している。 Golgi 野内には比較的少ないが, 補古期 のものでは小さい分泌顆粒, 釆粒体に混じて小架胞状の 粗面小胞体や free ribosomes がしばしば見出される (附図 18，22，23）。充盈期に近く分泌顆粒が核上部に 増加するにしたがい細胞質は周辺部に圧迫され，顆粒は 相互に接近するが粘液顆粒に比して密接するこ上は少な く，そこに小胞状の粗面小胞体や free ribosomes が介 在していることが多い（附図21，24，26，27）。充盈期 に分泌顆粒が核上部に旮满すると核はやや基底部に偏つ てみられるが粘液細胞でみられるよらに核周囲の細胞質 が圧排されることはなく、ここには常にかなり多くの粗

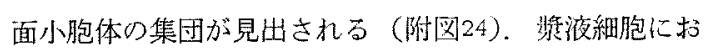
いては分泌周期を通じて，機能休止期ない乙補宎期には 多く，充盈期には比较的少ないが常にかなりの粗面小胞 
体を見出しうることは分泌顆粒の形態とともに粘液細胞 と異なる点である。

v) 分泌顆粒

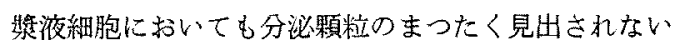
ものは認められず，機能休止期はほとんどないか，ごく 短か、と考えられる。分必顆粒を少数もつ細胞で観察す る上，小さい分泌顆粒注上部の Golgi 野内に見出さ れる(附図18，20，21，22）。この顆粒は，Golgi装置の 項で述べたごとく，内膑の拡大した Golgi 層板ないし Golgi 空胞と移行像が認められ，内腔心電子密度は次第 に大となり，大きさもます（附図18，20，21，22）。し かし，この時期の顆粒の内容は一般に充盈期にみられる 大きな成熟した顆粒に比べてやや粗精で雲絮状の模様が 認められることが多い（附図18，22）。この模様は顆粒 がさらに增大し，腺腔面細胞膜直下に移動する時期には 均質性無模造の顆粒になる。充盈期には核上部から腺腔 面にかけて，多数の分泌顆粒でみたされ，㢡液顆粒は互 に接近して存在するが多くの場合顆粒間に多少の原形質 層が介在し，そこに free ribosomes や小胞状の粗面小 胞体がかずかに分有している（附図21，24，26）。この 時期には Golgi 野内に分泌顆粒はむし万少なく顆粒形 成像も著明でなく，核上部の Golgi 装置おるびこれに 曲まれるGolgi 野は分泌顆粒の分布せぬ小野として認 められることが多いが，このことは，充㬈期における分 泌顆粒々 Golgi 装置との位置的関保について，粘液細 胞と漿波細胞とで異なる所見である(附図24)。

vi）細胞閒分泌細管

気管腺の漿液性終末部または半月の部分では腺細胞間 に細胞間分泌細管が存在することが知られているが現在 までに詳細な記載注行なわれていない，漿液細胞は隧接 細胞との間にしばしばよく発達した細胞間嵌合がみら

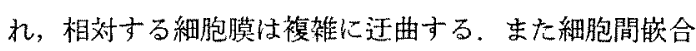
の部位にはときに種々の広さの細胞間隙がみられ，そこ に離開した細胞間嵌合によって生じたと思われる微鐡毛 状の㔖起が比較的疎に配列し，細胞に沿つて走る腔隙と して認められる(附図 3)。この場合，この腔隙の壁に は, desmosome または junctional complex 等の細胞接 着装置は見出されない：この所見はすでに晹上皮の吸収 細胞でよく知られている如く，細胞間嵌合によつて相接 する細胞間が固定さたは細胞機能状態に上り離開した腔 腺と考えられる。これに対し腺細胞間には，内腔が横断 ないし斜阯された多数の微䋐毛で内腔がみたされた細陌 がみられることが尚る（附図7，26，27）。この場台, 腔
は junctional complex ないし zonula occludens 样構 造を伴ならことにより2個以上の細胞間に成立する細管 状の腔であることが示唆される．この腔は光顕的に報告 されている細胞間分泌細管に相当するものと考えられ， 多数の切片について祫索したがなかなか見出しにくいこ とから，あまり発達はよくないるのと考えられる。

vii) その他の構造

i）ないしvi）に述べた諸構造のほかに，漿湤紐胞に もわず加の微細線維束 (附図18，19，20，23)，ライソ ゾームと考えられる高密度小体（附図 3，17，22，23， 24 ), 脂質滴（附図 3，17，19，22，24）等が認められ る。微細楾維束は主に核周囲部で粗面小胞体と采粒体之 が形成する小野の閏に見出される（附図19）。ライソン゙ 一ムと考元られる高密度小体は大小不同で大きさは 390 〜730nmであり円形楕円形ないし曲珠状等を呈し，緗胞 質全域に散在性にみられる．概して分泌顆粒の少ない細 胞や補充期の顆粓形成のさかんなものに多く見出される 傾向がある．脂䓄滴はこれよりもやや大きく $0.8 \sim 1.5 \mu$ でほぼ円形を呈し，周辺部に高密度の縁 (rim)をむち内 腔は空胞状で明るいものが多く、しばしば数個が集団を 作つて存在することがある。

5. 漿液細胞の分泌周期に忘ずる形態変化

前項に扔いて述べたごとき諸構造を含む蒋液細胞は， 分泌周期に応じて著明な形態学的変化を示す.このこと についてはすでに前述の各項において簡単に記载した が，ここでさらにその分泌周期を粘液細胞と同じく4 期 に大別し, 諸細胞小器官その他についての変化を詳述す る. 分泌周期の時期注細胞によりかなりの相異のあるこ 上は粘液部と同様で，隣接する細胞でも機能時期は必ず しも同一ではない，

1) 補充期初期（機能休止期）(附図 $3 ， 17 ， 18 ， 19$, 21, 22)

獎液紐胞についても，かなり多くの切片について詳し く観察したが，全く分泌顆粒の認められないいわゆる空 虚な細胞は見当らず，従来光顕的観察においていわれて いた機能休止期はきわめて短かいか，またはほとんどな いと思われるので，この時期はむしろ補充期初期として これに含めて記载を行ならのが至当であると考えられ る. 瑔液細胞は一般に立方形ないし円柱形で，やや広、 基底部老もち核は細胞のほぼ中央加少し基底部婂偏って 存在している. 分泌顆粒のごく少ない細胞について観察 すると，核は軽度に波状の襍曲を示す円形ないし棈円形 の輪廍をもち，異梊染色質の少ない比較的明調な核質を 
含むものが多いが，一方，かなり凹凸ある輸彰をもち， ときに深、切れ込みのある不規則の核をもつ細胞もみら れる（附図19）。核周囲部にはかなり多くの細胞質があ り,ここに粗面小胞体, 米粒体, 微細線維束等功ある. 核 上部から腺腔面に汃けては比較的広、細胞質野で，核上 部には小野をとり囲んでGolgi 装置が配列しておうり，小 さい幼若な分班顆粒はまずこの Golgi 野内に出現する。 Golgi 装置は Golgi 層板と Golgi 架胞が彎曲する索状 をなして多数みられ，これに密接してほほ球形高密度の 小体として分泌顆粒が出現する. Golgi 野内にはこの他 に Golgi 小胞, 少数の粗面小胞体, free ribosomes が ある. Golgi 野を構成する Golgi 装置の外側に は扁平 のう状の粗面小胞体, 米粒体, 微細線維束のみられるこ とは核周围部と同様である。

2 ) 補充期（附図20，21，23）

この時期には核上部にかなり多くの分泌顆粒がみられ るとともに, Golgi 野に扔ける顆粒形成像もよくみられ るようになる(附図20)，核上部 Golgi 装置周囲の所見 は, Golgi 空胞の搪大がみられ，内部は高電子密度とな り，形る円形，棈円形のもののほ加不規則のう状を呈 するものがしばしば見出されるよらになる。これらの Golgi 空胞に近接して球形 (円形)で，これと同様の電 子密度をもつ大小の分泌顆粒む見出される. 分泌顆粒仕 Golgi 野のみでなく，これをとり围む細胞質内にも多数 見出されるようになり，さらに，これらの顆粒恃大きさ を增すとともに漸次腺腔面优く移動し, 細胞先端部に 集積するようになる。しかし諳液細胞に扔いてはいわゆ る中間暗带に相当する所見は明膫には見出されない，浆 液細胞の腺腔面には形態不揄いの少数の微䑰毛の派生が あり，腺腔面細胞膜直下には均質性無椿造の薄層 があ り，以わゆる外形質層とも呼ばれる構造と考えられる （附図21）。補充期に㧍いては, 細胞先端部の 分必顆粒 はこの層より深部に位置し，顆粒の限界膜と腺腔面細胞 膜とが直接接していることはみられない，顆粒間をみ たす原形質内には粗面小胞体や系粒体がみられるがとく に Golgi 野内の幼若な分泌顆粒瀗接して小さい米粒 体がしばしば見出される。 また補充期初期（機能休止 期）に多くみられる高密度小体は，この時期には淢少 し,やや少ないよらに思われる。

3) 充盈期 (附図21，24，26，27）

補充期が進行し，核上部が分泌顆粒で允満するように なれば細胞は充盈期に入り，分泌顆粒の形成機能も逐次 隇衰する，核上部から腺腔面にかけて，滑面限界膜に包
まれ，中等電子密度の内容をもつ分泌顆粒が多数みられ る、大部分恃円形ないし棈円形の輸遊をむつが，ときに 不規則形のものが混在する。顆粒は限界膜をもつて互に 密接することもあるが，多くの場合顆粒閐汇は少量の原 形犋層が介在し，そこに小胞状や扁平のう状の粗 面小 胞体, free ribosomes が少数介在する. Golgi 装置任 Golgi 層板と Golgi 空胞とが主な要秦であるが，いず れも補充期に比して少数で, 長い索状構造を示さず, 空胞も小さいものが多い，核上部に括いては系粒体は Golgi 野の周囲㧍よび分必顆粒の間に認められる。また Golgi 野内に幼若应分泌顆粒もきわめて少ないので, Golgi 装置の存在する部位は恬とんど分泌顆粒を見出せ ぬ小野として認められるよらになる（附図24）。核は種 々の形態のものがみられ, 前述の 2 つの時期のものと性 状に変りはないが，緗胞基底部にかなり傓って存在する ものが多く，核周囲の原形質層もうすく少量となり，て こにみられる粗面小胞体や系粒体もわずかとなる，漿液 部においては腺腔は一般に狭く，狭小である. 充盈期に は核上部に蓄積する分泌顆柆のため，腺腔面はやや隆起 するのがみられる。ここには少数の微䊼毛があり，さら に細胞膜直下に法外形買層孔明膫汇認められる。

4) 排出期 (附図25)

装液細胞の分泌顆粒は粘液細胞のものに比してやや高 電子密度で小さいものが多い，また蔣溜顆粒の間にはか なりの細胞質が介在することも注目される所見である。 腺腔面は充盈期に扔いてみられたと同様, 腔に向つて乫 出する傾向はさらに著明となる。この場合む細胞表面か ら微揫毛の派生はあるが短かいものが多く，分布も一様 でない，また，従来腺腔面細胞膜直下に認められた均質 性無椿造のいわ的る外形質層は不明膫となり，小空胞が みられたり，表面細胞膜と分泌顆粒の滑面限界膜とが密 接する像をしばしば見出すことができると同時に隣接す る顆粒が限界膜を密接させてあることが多く認められる ようになる。このことは emiocytosis による顆䉼放出を 思わせる所見である。

6. Mitochondria-rich cell (oncocytes)

ヒ卜気管腺終末部には粘液細胞と洯液細胞の他に, 少 数ではあるが胞体が多数の釆粒体で充苪する細胞が存在 することが見出された（附図 $4 ， 5 ， 28 ， 29 ， 30 ， 31$ ）。 この細胞惊腺細胞と同じ腺管の構成にあずかり，腔に 面して腺細胞の間にこれと並列してみられる，腺上皮細 胞の間に単独または小集団をなして見出され，隣接する 細胞法粘液細胞の場合（附図4，5，31）も，茗液紐胞の 
昜合（附図28，30）も方。腺腔面は一般に平坦で，指 状の微咆毛の派生がみられる(附図28，29）。隣接細胞上 は腺腔端に颃いて junctional complexにより結合し， 樑部に向つて desmosome がみらられ（附図28）ほかに よく発達した細胞間获合がみられ（附图28，31），これ によつて隣揬緗胞と密接しているが，しばしばここが嚾 䦎し，狭、細胞間隙のある部位もある。基底面は㨁接ま たは筋上皮細胞を隔てて腺管をとりまく基底膜に相刘问

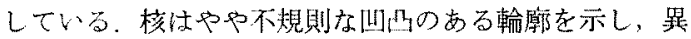

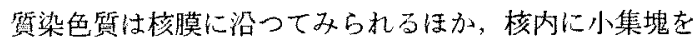
なして存在する（附图30，31）。核の位堛は緗胞に上り 種々で，基底部にあるもの（附図31），やや細胞先端部 に灀つてあるもの等がみられる。本細胞の特徽は胞体が 多数の米粒体によつてみたされるこ上である。この采粒 体江他の腺細胞内にみられるものに比して大きく，吅

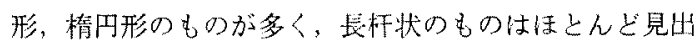
さ㧈ない cristue mitochondrialesは一般に筑状の paired membrane でその配列状態は個々の系粒体により かなりの相異があり，政密に配列する cristae tもつも の，柾なもの，部位により配列に柾密がみられるもの等

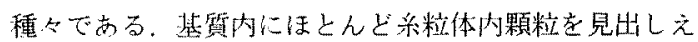
ないことも注目す心き所見である。これらの系粒体は五 にその限界膜密密接して胞体の大部分在みたしている (附罒4，5，28，29，30，31）。下の他，本細胞内に法 Golgi 装置，小胞体，高密度小体等引゙存在する，Golgi 裝犆は糸粒体群の間に混在して所々にみられる(附应

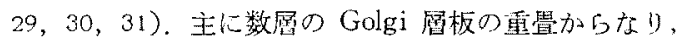
周井に少数の Golgi 小胞があり，これに近接してライ ソゾームまたはリボフスチン顆粒と考えられる内部に染 胞老含さ高密度小体の集団が存在するこしが多い（附㸚 29，30），滑面小胞体，粗面小胞体も存在する。滑面小 胞体は主に腺腔面細胞膜に近く狭、細胞筫野内に認めら れ，小胞状ないし細管状で，細胞により発達の程度には 相異がある(附図28)。粗面小胞体は少ないが，系粒体 群の間に介在する細胞翼内に子られ，多くは短加い扁平 のら状を呈し，疎に分布している（附図28，29，30， 31). Free ribosomes た polysomes はほとんど見出 されない、この稩胞は采粒体を豊䈏にもつが，Golgi 装 置, 滑面扰ざ粗面小胞体, ribosomes 等の発達は悪く 分泌機能を示唆する所見にそしいが，詳細に観祭子ると

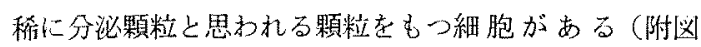
31）ここの顆粒は粘液細胞や菂液細胞のものに比しては るか心小さく円形で，滑面限界謨古ち，中等電子密度
の内容を含んで招り，細胞先端部の腺腔面直下儿集団 としてみられる。円形の核性基底部にあり，核上部の Golgi 装直の存在する小野を除いて胞体は采粒体で充满 している。糸粒体は円形，势円形のほかにかなり長い杆 状のものが多く混在し, 米粒体群の間には粗面小胞体, ribosomes も豊富である。Golgi 装置に接して分泌顆粒 形成像が認められ，纤若な分泌顆粒が存在する，ライソ ジームと思われる高密度の小体は主に核上部に散在性に あり，Golgi 野で分泌顆粒と密接しているものもみられ た.上述の所見は mitochondria-rich cell (oncocyte) が 分泌譏能を持つものもあることを示している（附図31）。

7. 導管上皮細胞

攻管腺終末部で腺腔内に排出された分泌物は，導管を 释て粘膜表面に達する，導管怡前に述べた如く，杯細胞 混ずる多列繊毛上皮の陌凹に明口するが，脆山は浅い 杯状のものや深い管状のもの等がある．陷凹部の上皮の 性:状は他の部と同溙の多列繊毛上皮である，導管は広い 内腔をもち，管腔を用んで高门柱形の細胞と，その基底 部にみられる基底細胞上からなる2列上皮である。この 上皮の外側は終末部に連続する基底膜によつてとり囲ま れ，これをへだてて結合組織に接している（固有膜） (附図 1)。粘膜上皮の陥凹と尊管上皮との境界は明睹 で，肖能者の細胞は腔に问つて多数の緎毛をもつが，後者 の細胞は䋐毛は持たず，雨者が混在することもみられな 以（附図 1)，導管上皮の队柱上皮細胞は管腔面に多数 の微䋐毛の派生がみられ，管膛面細胞脱直下には明嘹な 外形質層が存在する。この居より樑部に各種の䋛胞小器 官があり，核はやや媣部（基这部）に位置する，核上部

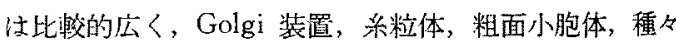
の大きさと形態をむつ多数の高密度小体があり混在して 見出される（附図 1)．また，ときに分泌顆粒々思われる 円形高密度の顆粒が細胞先端部に集団をなして見出され ることがある（附図1）。この細胞の Golgi 装置は核上 部にあり，主に Golgi 層板，Golgi 小胞からなるが各 要素の発達は一般に弱い，しかし，前述のごとき顆粒を もつものでは Golgi 装置の周柬に明調で小さい顆粒が 外られ，導管士上皮細胞の顆粒形成能の存在を示唆する所 見がある、この細胞の核下部は狭く，基底面に達するが 粗面小胞体沬少なく，多くの free ribosomes 杍よび少 数の系粒体がみられるのみである，細胞側面は管腔端に junctional complex があり，深部は隣接細胞と複雑に获 合することは終末部細胞とよく似ている(附図 1). Desmosome は比較的少ない，基底細胞は円柱上皮細胞の基 
底部の間にあり類円形で比較的明調な細胞買をるつ細胞 である（附図 1)，核は胞体のほぼ中央にあり，怪度に 凹凸を示寸が，円形ないし棈円形である，細胞小器官に そしく，核周囲部に系粒体，微細線維束，グリコゲン顆 粒等が疎に配列しているが，粗面小胞体，free ribosomes は少ない，ライソゾームと思わ机る高密度小体も 存在する（附図 1)。この細胞も隣接細胞とは複雑な蚮 合をもつて接し，基底面で基成膜に值接している。

\section{8. 筋上皮細胞}

気管腺終末部(分泌部) の腺細胞上腺管をとりまく基 底膜との間には，この画者にはさまれて筋上皮紐胞が見 出される（附図2，3，4，8，17，32，33）。この細胞は粘 液性終末部にも，繁滩性終末部にも同様に存在し，切断 面加ら推察すると，細長い外形をもつと考えられる。基 底膜に対寸る面は一般に平坦なことが多いが，ときに舌 状の突出を示すことや不規則な几四凹みることがある。

碳接寸る䇟細胞間に腺細胞の基底部が介在していること が多いが，筋上皮細胞吕相互に複雑な蚮合をもつて接し ている所見もみられる(附园 $2 ， 33$ ).腺細胞の基底面と筋 上皮細胞との接触面は所々で簡単な稩胞間获台をもつて 接し，上きに狭、間隚をみるこ上がある(附図3，8，33）. 核は胞体のほぼ中央にあり，長棈円形で，主にその闻極 に杀粒体，粗面小胞体，Golgi 装置，中心子等の細胞小 器官があるが，他は豊富な箭微原線維によつて光渵して いる（附图32，33），微原線維束間にも少数の糸粒体や free ribosomes が混在する。 また微原線維束の所々に 不規則斑紋状の高密度の小野があり，乙の一部は基底面 細胞膜に接しているのが認められる（附図33），細胞内 にはこのほかライソン゙ームと思われる高密度顆粒がみら れ核周囲部や筋微原線維束間に存在寸る(附図33)。しか し，パイサイトーシスを示す小胞は少なく，わずかに 基底膜に面して小集団をなして見出されることがある。 核から辺縁部に向つて細胞は次第に細くなる偩向を示寸 （附図32），詳細に観察すると，腺管老上りまく基底膜 の内側に大小の筋上皮科胞の断面がみられるが，大きな 断面をもつものの閒にはその一側また周囲を基底膜に包

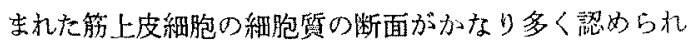
ることがある、これは拉そらく，筋上皮細胞の周辺部か またはこれから出される突起の一部と考えられ，本細胞 から若干の細胞翼性突起が出されることを示晙する。し

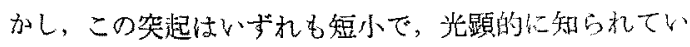

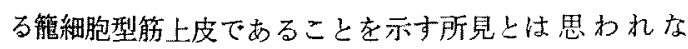
い.すなかち、ここにみられる筋上皮細胞は多少の細胞
質突起を出寸が，概して平滑筋型のもので互に平行して 比較的密に腺管莨囲んで配列していると考えられる（附 図33).

\section{考 察}

1. 父管腺の一般的棈造

ヒトおよび各種禁椎動物の気道粘膜の微細棰造に関す る報告は、粘膜上皮については数多く行なわれている が、気管腺に関寸るものは少ない，上卜の気管腺の光学 顕微鏡的研究も少京いが，このことについては金子がが その論文のなかで研究の歴史的考察として強調してい る。著者はそれ以後の文献，著書等について精查した が，光学䫖微鏡による詳細な系統的な研究は少なく，雷 子影微鏡を用いた検索もほとんどないといつても過霄で はない。この点に招いて、金子゙の記载蚛，気管腺の一

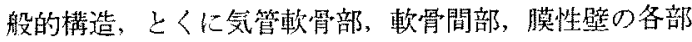

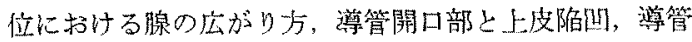
上皮，終末部上皮の形態上分布等に関して詳細な観察吕 なされた上、紐胞について女詳䋥に述べており貴重なる

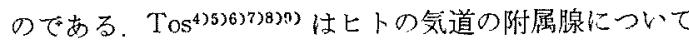
かなり広筝な研究を行なつているが，彼は独特のwholemount method により粘膜全读橪本を作製し，気管腺の 分布状態，数，腺の形態，拡がり方等について光影的に 钼察している。この報告は主に弱扰大による組織学的観

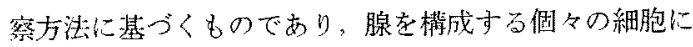
関する詳細な細胞学的所見は含まれていない，私は今回 の電子顕微鏡に上る気管腺の観察においては, 弱执大焉 真の梌索上 semi-thinsections を用いて前者との比較、お よび金子゙の報告との参照を行ないながら腺の一般的構 造についても検討を加えた，気管腺は導管により杯細胞 混ずる多列瀻毛上皮からなる粘膜上皮の陌回の底に開 口する．陷凹には浅いすり鉢状のものや，やや迁曲する 管状のもの要で種々であるが，上皮の性状住陷凹部上導 管とで明確に相異する。すなわち，陷四部は表面上皮と 同じ多列瀻毛上皮であるが，導管上皮には繊毛をしつ維 胞はなく，两者の境界は明膫て，筫管においては，管腔 面直下に分泌顆粒七思われる高䉥度顆粒をるつ細胞をみ ることがある。この細胞の核上部には条粒体や粗面小胞 体も多く，Golgi 装置の周囲には少数の低密度の队形顆

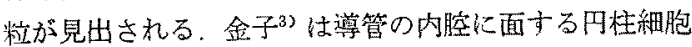
の先端部に PAS 反応陽性で睡液耐性の物犋が萿積され ていることを見出し，これが本䋖胞の分泌顆壮の其榠で あるか否か，さらには本細胞に分泌機能が存在するか否 かについて断定することは光影䂓察の所見からは图難で 
あるとしている。私の観察した管腔面直下の顆粒の集団 は招弚らく金子3)の PAS 陽性物質に一致するものと考 えられ，高密度顆粒の集団であることが明らかとなっ た，分泌機能に関しては，この顆粒が存在するほかに， 本緗胞内に細胞小器官の豊富なこと，Golgi 装置の周囲 に顆粩形成像を兒出すこと，管腔面細胞膜に eruptocrine processによる顆粒排出を思わせる著明な陥凹を認め ること等から，導管上皮細胞には分泌機能を持つものが あると教えられる。獐管は 2 列上皮で，腔に面して円柱 紐胞が必接して並列し，この細胞の基底部にはさまれて 頪円形の基底細胞がある。分泌機能はこの円柱細胞には 認められるが，基底細胞にはみられず，細胞内にはしば

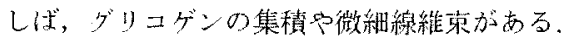

筫管に続いて終非部（分泌部）がある。終未部の腺管

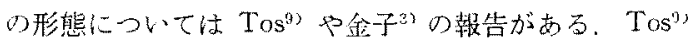

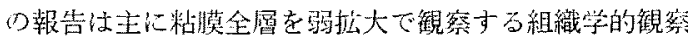
によるものであり，金子3゙ 注バラフィン包埋した材料を 連続切片とし，光学顕微鏡に上り㛟素を行なつたものて 两者の方法にはかなりの相異がある、彼等の㓋察によれ

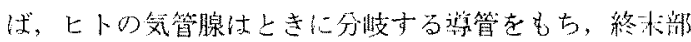
は管状ないし胞状在なし，分岥加的的るとしている。

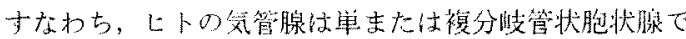
两る。釉末部緗胞についても Tarchetti (Heiss²)引湖)

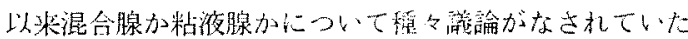
が, 近年の研究者の多くは混合腺説をとつている。金子 はこの点についても最も詳細に観察して招り，粘液紐胞

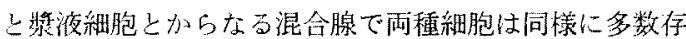
在すると述べている，さらに雨種腺細胞の分布状態につ いても，粘液細胞は導管に続く腺管（粘液管）を構成 し，蒋液細胞は末梢沉存在して粘液管に開口する漿液性 腺管を作り，粘液管壁とくにその末端に近く獎液紐胞力 らなる半月をみるとしている，本研究においては超赫切 片の観察から終末部の形態を充分論ずることはできない が，腺細胞の配列と分布状態については金子ª所見上 一致する成續在得た，さらに雨種腺細胞の分布状態を超 薄切片で観察する上，断面にみられる腺細胞の分布は複

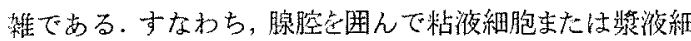
胞のみからなる終末部り断面がもつとも一般的で多数み られるが，このほかに，腺腔を囲んで粘液細胞群之禁液 洲胞群が各タこの一側を占めてこれをとり囲んでいるこ 上も加なり多く見出され，上きに雨種腺練胞が泿在する

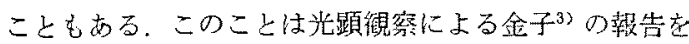
雷顕的に確認するものであるとともに超薄切片上では粘
液部と獎液部との境界部が切断されると両者が混在して

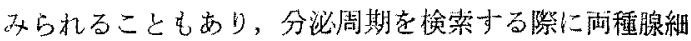
胞を判別する場合注意が肝要で，特に休止期ないし補充 期初期に注目すべき所見である。切の気管腺は混合腺 であり，ての特徴とされている半月 (demilune, Halbmond) の存在については Tarchetti (Heiss") 引用) に よつてはじ的て記載されている，混合腺に扔ける半月の 形成については，唾液腺に関して，Heidenhain の有名 な獎液細胞の粘液化説 Verschleimungstheorie がある が，ヒトの気管腺についての報告の中で金子”゙は「この

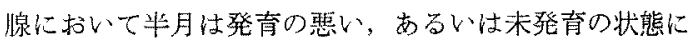
ある留液性腺管であると考えられる」としてHeidenhain の説汢気管腺にはあてはまらないと述べている。䇩湿䋩 繁に上扎ば，㫤液細胞群は，同一腺腔の全周を困む細 胞集団としてみられる場合，同一腺腔を囲んでその一 側は粘液細胞群，他の一側には藤液細胞群が位置する場 台，同一腺腔を阙種細胞が混在して团む場合等がみられ た。しかし，いずれの場合に扔いても萕液細胞は明眿な 分泌周期老もつことが認められ，核や細胞質内の諸梅造 にPyknose や変性を思わせる所見は見出さ礼ないこ

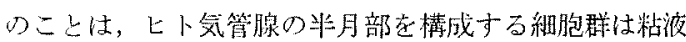
化した上皮細胞により圧迫された烝淡細胞群ではなく， 発育の悪い，あるい怄発育の状態にある㡜液性終末部 であるとする金子がの説は妥当なものであると考えられ る.

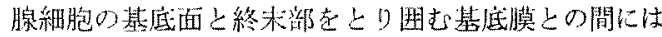
多数の筋上皮細胞がある。この細胞の形態についても記 載は之しく，古くFuchs-Wolfring (Heiss ${ }^{2)}$ 引用) が籠 細胞として述べたほか恃金子3) の研究までほとんど明確 店記载怯行なわれていない 筋上皮細胞については汗 腺, 乳腺, 唾液腺等でよく観繁されており，平滑筋細胞 型上簿細胞型との2 種に分類され，前者は中央部が太い 紡鏈形で，後者は中央の有核部から四方に分岐する多く の笑起を出すヒトデ形のものとされている，気管腺の筋 上皮細胞についてみると，横断像では腺細胞の基底面に 多少の間隔をつて配列して扝り，その長軸注ほぼ平行 して灰らんでいる，腺細胞と対向する面は平坦なこと も，簡単な細胞間嵌合のあることもみられる，基底膜に 对する面も平坦な場合，㹩く禤曲する場合等がある。核 周罒部には細胞澌が豊富で，ここに種々の細胞小器官が 南るが，この部を除いて細胞は多数の筋微原線維 myofilamentsによってみたされ，ここには多くのいわゆる dense body が介在している。細胞は周辺部に向 5 にし 
たがつてその厚さを減ずる，腺細胞基底面に沿つて詳細 に観察すると，筋上皮細胞の末端部之思われる構造がみ られる．末端部は単一でなく細か、分岐を示し，小突起 をもち，隣接する細胞上の狭い間隙に基底膜様權造が介 在しているのがみられることが多い またときに比較的 厚径の大なる部位で筋上皮細胞がその側面をもつて互に 密接することもある。しかし，細い末端部が互に密接す る像はみられない：これらの所見から気管腺の筋上皮細

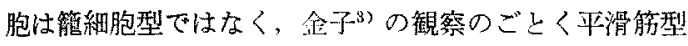
であることが示唆される。

終末部内にきわめて系粒体に富む細胞が見出される。 この䋺胞俚 1 個ないし少数個の集団として腺細胞となら んで出現し，先端部は腔に面し，基底面は腺をとり围む 基底膜に接している.細胞はほぼけ央に円形の核をもち， 胞体沬多数の類円形の采粒体で充満し，Golgi 装置や小 胞体の発達は悪いが，かなり多くの高密度小体が采粒体 に混在して見出される。従来, 耳下腺その他の唾液腺, 鼻腺 ${ }^{(6)}$ 队喉頭 ${ }^{17)}$, 気管支の腺, さらに膵, 胃腺, 乳腺な どに oncocyte と呼ばれる特異な緗胞が出現することが 知られている。この細胞は比較的大きな細胞で, 細胞愿 は顆粒状を呈し，酸好性であることを特徴としている． この種の細胞については, Schaffer ${ }^{18)} か ゙$ 初めて記載し，

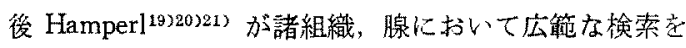
行ならと共に oncocytes, Onkozyten と呼んだ。また。 耳下腺等でこの種の細胞からなる蕾癌形成のあることが 見出され, Warthin's tumor (Tandler ら, ${ }^{22}$ Warthin ${ }^{23}$ ) として知られている。電子顕微鏡による検余が進むにつ れて (Tandler ${ }^{24)}$, Tandler et al. ${ }^{25)}$, 神田等 ${ }^{26)}$, Hübner et al. ${ }^{27}$, Matsuba et al. ${ }^{29)}$, Shimono et a1. $\left.{ }^{291}\right)$, この細胞の 形態は次第に明らかにされつつあるが，oncocyte の出 現する意義や機能については不明な点が多く意見も一致 していない，正常組織または腫瘍においてこの細胞を検 索した報告を総合すると，光影的に顆粒で渵たされてい るといわれた細胞質には，多数の采粒体が无满し，他の 細胞小器官の発達はきわめて悪い特徵ある形態をむつこ とが明らかとなった。私の観察した mitochondria 老 富にもつ䋖胞は形態学的に oncocyte にきわめて類似し ている，すなっち，腺紐胞とならんで，腺腔に面し，絒 胞側面には腔端に junctional complex の形成があり, 深部に desmosome もみられ，裂接細胞と密接してい る、基底面も筋上皮細胞を介するかまたは㨁接基底膜に 接している。この細胞の意義については，光学ならびに 電子䫓徽鏡による稪察の結果種々の見解がある。尊管上
皮あるいは腺上皮細胞に由来するもので，変性または transformation によって生ずるとする説 (Hamperl21), Ackerman $^{301}, \operatorname{Roter}^{31}$, Matsuba et al..28), Tandler ${ }^{2425)}$, 神田 ${ }^{26)}$ )，筋上皮細胞が分化することによるとする説 (Hiibner27) 等がある。気管腺沈みられたこの䋖胞は終 末部にしばしば胃出され，詳細にみると，前述のごとき 系粒体の汪かに Golgi 装置, 粗面および滑面小胞体, ライソゾームと思われる高密度顆粒が存在する。滑面小 胞体江細胞先端部に多く, さらに腺腔面に近く小円形の 中等電子密度の分泌顆粒の集団をもつものもみられた。 現在までの oncocyte の観察索行なつた報告の中にこの ような顆粒の存在を記载したものは見当らない神田 ${ }^{20}$ らは正常七卜喠液腺内の oncocyte について䘽察し, こ の緗胞は腺細胞の transformation によつて生ずるもの と推定し, 粗面小胞体, Golgi 装置など顆粒形成機序に 関与する形態がみられす，腺細胞本来の機能が全く失な われているとしている，著者の钼察した分泌顆粒は比䡆 的小さいが滑面限界膜上中等電子密度の内容をもつてい る。また，核上部に Golgi 装笽があり周囲に少数の顆 粒が存在し，影粒形成機能をもつことを示惨する所見が あり,さらに細胞先端部にかなり多くの滑面小胞体を含 むものもみられる。このことは、ヒ下気管腺のい和ゆる oncocyte は腺細胞に由来することを强く支持する所見 であると考えられる。ここに出現する oncocyte は本来 の腺細胞に比して Golgi 装瑻, 粗面小胞体およびリホ⿺ ジームにそしく，系粒体稜が疎で明調な基質をもち膨化 傾向を示す采粒体之，多くのライソゾーム李たは cytolysomeをもつこと等特徴のある形態を示し，腺細胞の regressive degeneration 在示唆する棈造が見出される ことが明らかとなった。

2. 気管腺の分泌機能上分泌周期について

ヒトの気管腺は混合腺であり，終本部には粘液細胞上 墏液細胞とがみられ，両種腺細胞は分泌周期の各㭙期に 上り，それぞれ異なつた特徴ある形態変化京示す。上卜 の気道附属腺に関する細胞学的研究は, 光学顕徽鏡によ

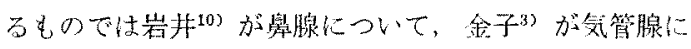
つけて、それてそれ詳細な钼察在行なっている。立た，

Lamb et al. ${ }^{3233)}$ (大気算支腺について組織化学的および autoradiography に上万検索を行ない，粘液顆粒扔上び 頮液顆粒の化学的性状の詳細について述べている。これ によれば粘液顆粒拉よび䏺液顆粒が sialic acid や sulphate などを共通にもつことが示されており画種顆粒に 類似性のあることが理解される，電子影微鏡による観察 
は，睤腺について，高棉 ${ }^{11}$ と增田 ${ }^{12}$ がそれぞれ樂液細胞 と粘液細胞とを分担してその微細構造, 分泌周期に応ず る腺細胞の微細構造の变化を詳しく追求している。しか し，七トの父管腺の終末部細胞を詳細に電顕的に観察し た報告は見当らない，金子 ${ }^{3}$ 注七卜気管腺の粘䍇細胞お よび蒜液細胞の分泌機能相をそれぞれ 4 期に分けて記载 している.電子顕微鏡的観察の埸合は, 舁腺についての高 橋11や増由 ${ }^{12}$ の報告のごとく，分泌周期をさらに細かく 区分することができるが，本観察では基本的には金子” にしたがい4 期に区分し，なお，補充期については補充 期初期とそれよりやや進行した補充期とに分けて補充期 初期は光影的には顆粒をほとんど見出しえない䇥虚な時 期に相当すると考えてその微細構造を記裁した．粘淮細 胞を電顕的に覾察すると, 分泌顆粒の数や, 分布状態, さらにその形態学的性状については，細胞によつて著し い相異があり種々の分泌機能相を示すものがみられる。 しかし，金子3)の光㩆観察に㧍いて述べられているごと き，分泌物空虚な細胞は見出しえず，Golgi 装置の周困 または細胞先端部にごく少数の分泌顆粒が認められるこ とが多く, 粘液細胞では機能休止期はほとんどないかま

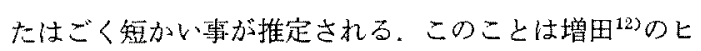
卜舅腺粘液細胞に打ける所見とよく一致する. 補充期に 入ると, 細胞小器官の発達は著明となり, とくに核上部 の Golgi 装置は Golgi 層板が長い索状を呈し、これが 核上部の細胞質の小野をとり囲むように配列し，いわゆ る Golgi 野を形成するようになるが，分必顆粒はまず この Golgi 野内に出現する。顆粒は次第に大きさと数 を增し，互に密接するようになる，さらに数を増すと， 分泌顆粒は核上部でこれに近接してみえる集団と，細胞 先端部で管腔面直下に集まるものとの2 群となり，両者 の閏には分泌顆粒のほとんどみられない細胞質の帯状屠 が介在するようになる。このことはすでに金子゙3が光顥 により指摘して㧍り，これと似た所見は横地 ${ }^{(5)}$ が十二 指晹腺緗胞で見出し中間暗带と呼んでいる。ここには Golgi装置やその他の緗胞小器官が豊富に見出されるが，

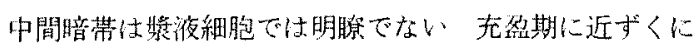
つれて綝胞先端部および核上部にそれぞれ分泌顆粒が增 加し，このため中閒暗帯はせまくなり漸次細胞側面に压 排されて不明瞭になる。充盈期で顆粒が練胞内に立満す るようになると, 核汶細胞基底部に圧迫され, 細胞質は わずかに顆粒間に見出され，系粒体も顆粒に混して少数 認められるのみとなる。粘液顆粒の形成の埸が Golgi 装置であることは前述の補充期の所兒から明膫である。
充盈期にみられる顆粒は比較的大で細胞内に充满し，核 は基底部に圧迫される。この時期に細胞先端部が腺腔に 向つて丘状に膨隆することがしばしばみられ，表面に派 生する微䋐毛が減少またはほとんど消失することもある。 表面細胞膜直下の外形質層も不明瞭となり表面細胞膜と 分泌顆粒限界膜とが密接する所見や, 半球状の腔に開口 する宿凹をみることがある。また細胞内の顆粒はときに ゆ合することもみられるので，おそらく粘液細胞の分必 顆粒放出機序は emiocytosis により行なわれることが 考えられ，また顆粒は相互が中合することにより腺腔に 連続する腔在経て順次に放出される機粠む推定される. Ichikawa ${ }^{34)}$ はパンクレオザイミンで刺激した犬の膵外 分泌細胞で顆粒放出は細胞膜之顆粒限界膜のゆ合と開口 によつて行なわれ，その顆粒に他の顆粒がゆ合連絡する ことによりさらに急速な放出機構を想定している。この 場合，顆粒が連珠状に数個ならぶ所見を観察している が, 本研究に扔ける粘液細胞では 2,3 個が連結してい るのがみられるが，その頻度は少なく，粘液顆粒の放出 は比較的緩徐であることが推定される. 従来, 粘液細胞 の微細棈造については光顕的に詳細な検索がなされてお り, 藤井 ${ }^{35}$ は偽么チン卵紧のう腫内面上皮の細胞学的研 究に朽いて, また大石 ${ }^{36377) 38}$ ) は人胃の細胞学的研究にお いて, 粘液細胞を粘液細胞型上皮細胞之杯細胞型上皮細 胞の 2 型に区別して記载している。すなわち，前者は胃 腺（胃底腺, 固有胃腺) 副細胞, 幽門腺, 十二指腸腺の 細胞がこれに属し，核上部から細胞先端部に集積する分 泌顆粒間に常に糸粒体や Golgi 装置が混在して見出さ れる.これに対し，後者には胃上皮細胞や腸上皮の杯状 細胞がこれに属し，粘液顆粒集程部はいわゆる杯（サカ ズキ）を形成し，来粒体やGolgi 装置はこの部に密接 して見出されることはあるが，杯の内部に侵入すること はないとしている。胃上皮細胞と副細胞の微細構造の相 買に関しては柴崎39 が電顕的にも確認した。気管腺の粘 淮細胞は、上記の分類によれば，粘液細胞型上皮細胞に 属することが明らかとなった。本細胞の核上部には多数

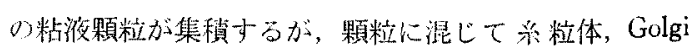
装置, 粗面小胞体等の細胞小器官が見出され，いわ帏る 杯（サカズキ)を構成しない

㢡液細胞の分泌周期も4期に分けて記載したが，本細 胞においても分泌顆粒をむたぬいわゆる空虚な細胞はほ とんど見出しえずごく少数の顆粒をもつことが多い，こ の場合, 細胞内には粘腹細胞よりもはる加に豊富化粗面 小胞体をもつことが認められ，扇平のう状で核周囲部か 
ら核上部にわたつて分布している，さらに漿液細胞はす ベての分泌周期を通じて常にかなり多くの粗面小胞体を もつことが明らかとなつた，補充期には分泌顆粒は核上 部の Golgi 装置周囲に最初に出現する。これらは逐次 数を增し，大きさもますが，中間暗帯に相当する所見は 見出されない，分泌顆粒注滑面限界膜に包まれ，内容は ほぼ均僙性で顆粒により若干の電子密度の相異がみら れ，とくに Golgi 装置周囲にあるものでは高密度のも のが多く，釆粒体と密接している所見がしばしば見出さ れる，鼻腺の漿液細胞の分泌顆粒産生について，岩井 ${ }^{10}$ は光影観察により糸粒体から形成されるとした，高橋11 は電䫓観察を行ない，分泌初期には Golgi 装置におい て，補充期加充盈期にかけては系粒体加ら形成される と述べている，本観察においては漿液細胞の分泌顆粒が 糸粒体から形成されることを示唆する所見㤝見出されず 小胞体，糸粒体の関与の下で，Golgi 装置において可視 的顆粒が形成されることが明らかとなつた，補充期が進 むにつれて分必顆粒は核上部に増加するが，顆粒は互い に密接する傾向は少なく，原形質層をーだてて存在す る.しかし，補充期末期加ら充盈期に至るとゆ合する顆 粒もみられるよ5になる。排出期には腺腔面細胞膜がし ばしば丘状に突出し，分泌顆粒限界膜が細胞膜と密接す ることもみられ emiocytosis による顆粒放出を示唆する 所見吕得られた，漿液細胞間には，狭、細胞間細管が見 出されるが管㓐端には junctional complex がみられる こと，腔内に微縺毛の派生があり，ときには管腔がみた されるほどであること等の所見がある，しかし見出すこ とはなかなか困難で詳紐な観察はなしえなかつた。

\section{結語}

手術時に採取したヒトの気管粘膜を用いて，従来ほと んど報告のない気管腺の超微細構造を電子顕微鏡を用い て観察した。

ヒトの気管腺は主に粘膜下組織内にあり，単または複 分岐管状胞状腺で，遒管と分泌部（終末部）とからな り，分泌部は粘液細胞と等液細胞とからなる混合腺で， その分布状態には規則性があり，尊管に続いて粘液細胞 からなる粘液部があり，その末端側に奟液細胞からなる 漿液部がある。獎液部はしばしば半月を構成する。分泌 部には平滑筋細胞型の筋上皮細胞が存在し，腺体は外側 を基底膜と結合組織とからなる固有膜に包まれる。

尊管は 2 列上皮で管腔に面する高円柱細胞と基底細胞 とから成る. 高円柱細胞怙ときに円形顆粒をもち分泌機 能の存在を示唆する所見がある。
粘液細胞と浆液細胞についてそれぞれその微細構造を 明らかにするととむに，分泌周期に応ずる形態変化を追 求し，分泌機構を形態学的に解明した。

槳液性腺管抽よび半月を構成する浆液細胞の間に形秥 学的な相異はない

分泌部上皮内に mitochondria-rich cell (oncocyte) が 出現することがあり，ま机に小さい分泌顆粒をもつもの がみられた。

分泌部において，腺細胞基底部にかなり多くの平滑筋 細胞型の筋上皮細胞があるが，その所見を述べた。

\section{文献}

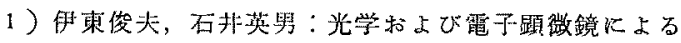
気道々食道粘膜の形態学——瀻毛上皮々重㬝扁平上皮

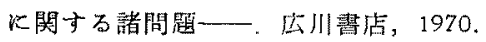

2) Heiss, R.: Luftröhre. (Hrsg. v.) Möllendorf: Handbuch der mikroskopischen Anatomie des Menschen. Bd. 5, Teil 3;742-750, 1936.

3）全于 宽：人の気管腺の組䋨学的业ひ汇細胞学的研 究。日組録，24；155-185，1963.

4) Tos, M.: Development of the tracheal glands in man. Acta Path. Microbiol., Scand., 68 (Suppl. 185); $1130,1966$.

5) Tos, M.: Development of the mucous glands in the human main bronchus. Anat. Anz., 123;376389,1968 a.

6) Tos, M.: Distribution and situation of the mucous glands in the main bronchus of human foetus. Anat. Anz., $123 ; 481-495,1968$. b.

7) Tos, M.: Topography of tracheal mucous glands in childxen. J. Otolaryng., 83 ; 1073-1087, 1969.

8) Tos, M.: Mucous glands in the trachea in children: Quantitative studies. Anat. Anz., 126 ; 146160, 1970. a.

9) Tos, M.: Anatomy of the tracheal mucous glands in man. Arch. Otolaryng., 92;132-137, 1970. b.

10）岩井宏方：人躬腺の形熊学的研究。日耳舆，61; 1454-1472, 1958.

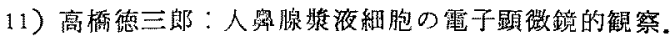
日耳鼻，64；51-66，1961.

12）增田隆正：人播腺粘液細胞の電子顥微鏡的穓察。日 耳算， $65 ; 952-976,1962$.

13) Luft, J.H.: Improvements in epoxy resin embedding methods. J. Biophys. and Biochem. Cytol., 9 ; 
409-414, 1961.

14) Bouteille, M., Kalifat, S.R. and Delarue, J.: Ultrastructural variations of nuclear bodies in human disease. J. Ultrastruct. Res., $19 ; 474-486,1967$.

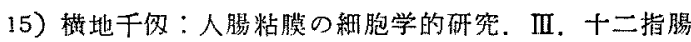
腺飞就て。組淾，2；13-27，1951.

16) Schoolman, J.G.: The oncocyte in nasal mucous membrane. Arch. Otolaryng., 51 ; 223-236, 1950.

17) Som, M.L. and Peimer, Q.: Oncocytic cystadenoma of the larynx. Ann. Otol., $58 ; 234-242,1949$.

18) Schaffer, J.: Beiträge zur Histologie menschlicher Organe, IV-VIl. S.B. Kais. Akad. Wiss. (Wien) Math. Nat. Classe, Abt. 3, $106 ; 353$, 1897. (Hamperl 引 用）

19) Hamperl, H.: Beiträge zur normalen und pathologischen Histologie menschlicher Speicheldrüsen. $Z$. mikrosk. - anat. Forsch., $27 ; 1-55,1931$. a.

20) Hamperl, H.: Über besondere Zellen in alternden Mundspeicheldrüsen (Onkocyten) und ihre Beziehung. en zu den Adenolymphomen und Adenomen. Virchows Arch. path. Anat., 291 ; 704-705, 1933.

21) Hamperl, H.: Über das Vorkommen von Onkozyten in verschiedenen Organen und ihren Geschw. ülsten. Virchows Arch. path. Anat., 298:327-375, 1936.

22) Tandler, B. and Shipkey, F.: Ultrastructure of Warthin's Tumor. J. Ultrastruct. Res., $11 ; 292-314$, 1964.

23) Warthin, A.S.: Papillary cystadenoma lymphomatosum: A rare teratoid of the parotid region. J. Cancer Res., 13;116-125, 1929.

24) Tandler, B.: Fine structure of oncocytes in human salivary glands. Virchows Arch. path. Anat., 341 ; $317-326,1966$.

25) Tandler, B., Hutter, R.V.P., and Erlandson, R.A.: Ultrastructure of oncocytoma of the parotid gland. Lab. Invest., $23: 567-580,1970$.

26)神由敬, 結束温, 北村武, 金子敏郎: 正常人

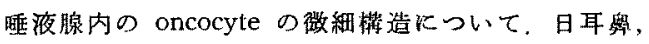
77 ; 199-202, 1974.

27) Hübner, G., Paulussen, $F$. und Kleinsasser, $O$.: Zur Feinstruktur und Genese der Onkocyten. Virch ows Arch. path. Anat., 343; 34-50, 1967.
28) Matsuba, K., Takizawa, T., and Thurlbeck, W. $M$.: Oncocytes in human bronchial mucous glands. Thorax, $27 ; 181-184,1972$.

29) Shimono, M., and Yamamura, T.: Ultrastructures of the oncocyte in normal human palatine salivary glands. J. Electron Microscopy, 24; 119-121, 1975.

30) Ackerman, L.V.: Oncocytoma of the parotid gland. Arch. path., 36 ; 508-511, 1943.

31) Rother, P.: Zur Zytologie und Zytochemie. der Onkozyten. Z. mikrosk.-anat. Forșch., 71,;207-228, 1964.

32) Lamb, D. and Reid, L.: Histochemical types of acidic glycoprotein produced by mucous cells of the tracheobronchial glands in man. J. Path., $98 ; 213-$ $229,1969$.

33) Lamb, D. and Reid, L.: Histochemical and autoradiographic investigation of the serous cells of the human bronchial glands. J. Path., $100 ; 127-138$, $19 ? 0$.

34) Ichikarva, A.: Fine structural changes in response to hormonal stimulation of the perfused canine pancreas. J. Cell Biol., 24 ; 369-385, 1965.

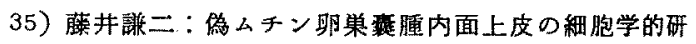
宛. 臨床座科婦人科，19；181，1944. (大石引用).

36）大石和子：人青上皮の細胞学的研觉，I．盟上皮の ゴルデ装圈に就いて，東京女子医学専門学校；1-15 1946.

37）大石和于：人胃上皮の細胞学的研究：II．胃上皮の ミトュンドリフに就て，東京女子医学専門学校；1-21, 1947.

38）大石和子：人胃腺の細胞学的研犯．III，副細胞の 細胞学的研究. 東京女子医学専門学校；1-34,1947.

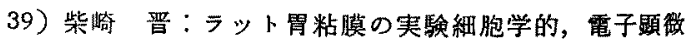
鏡的研先。日組録，21；251-288，1961。

\section{附図説明}

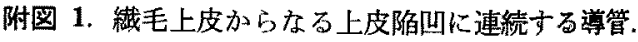
$\times 4300$

附图 2. 粘液性終末部 (弱拡大写真)。 $\times 4400$

附図 3. 獎液性終末部 (弱㹡大写真). $\times 4300$

附图 4, 粘液性終末部, $\times 6000$

附図 5. 粘液性終末部。Golgi 装㯰; $\times 6100$

附図 6. 粘液性終末部。微細線維束, $\times 5500$

附図 7. 然液性終末部. $\times 6300$ 
中山論文附図（1）
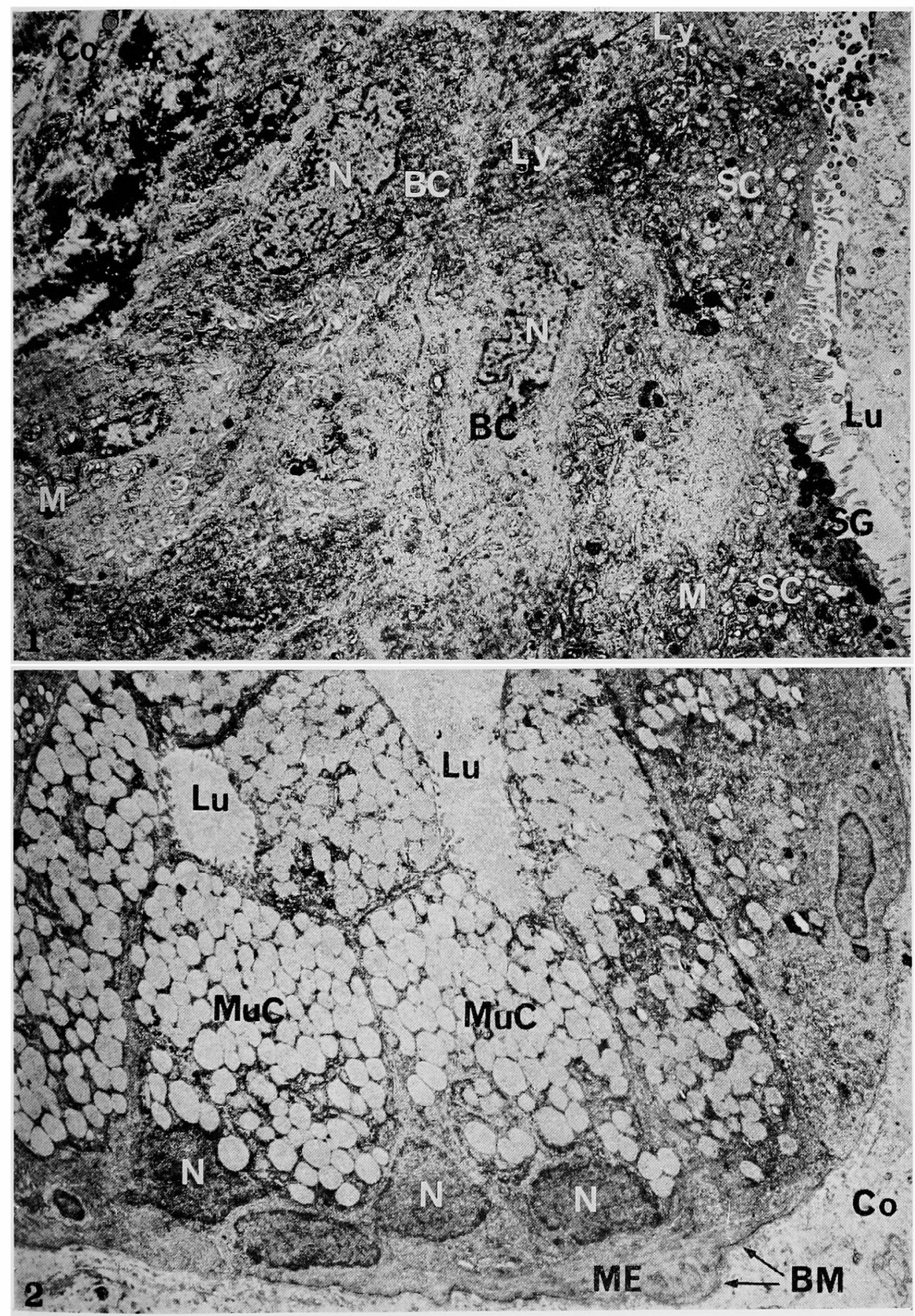
中山諭文附図 (2)
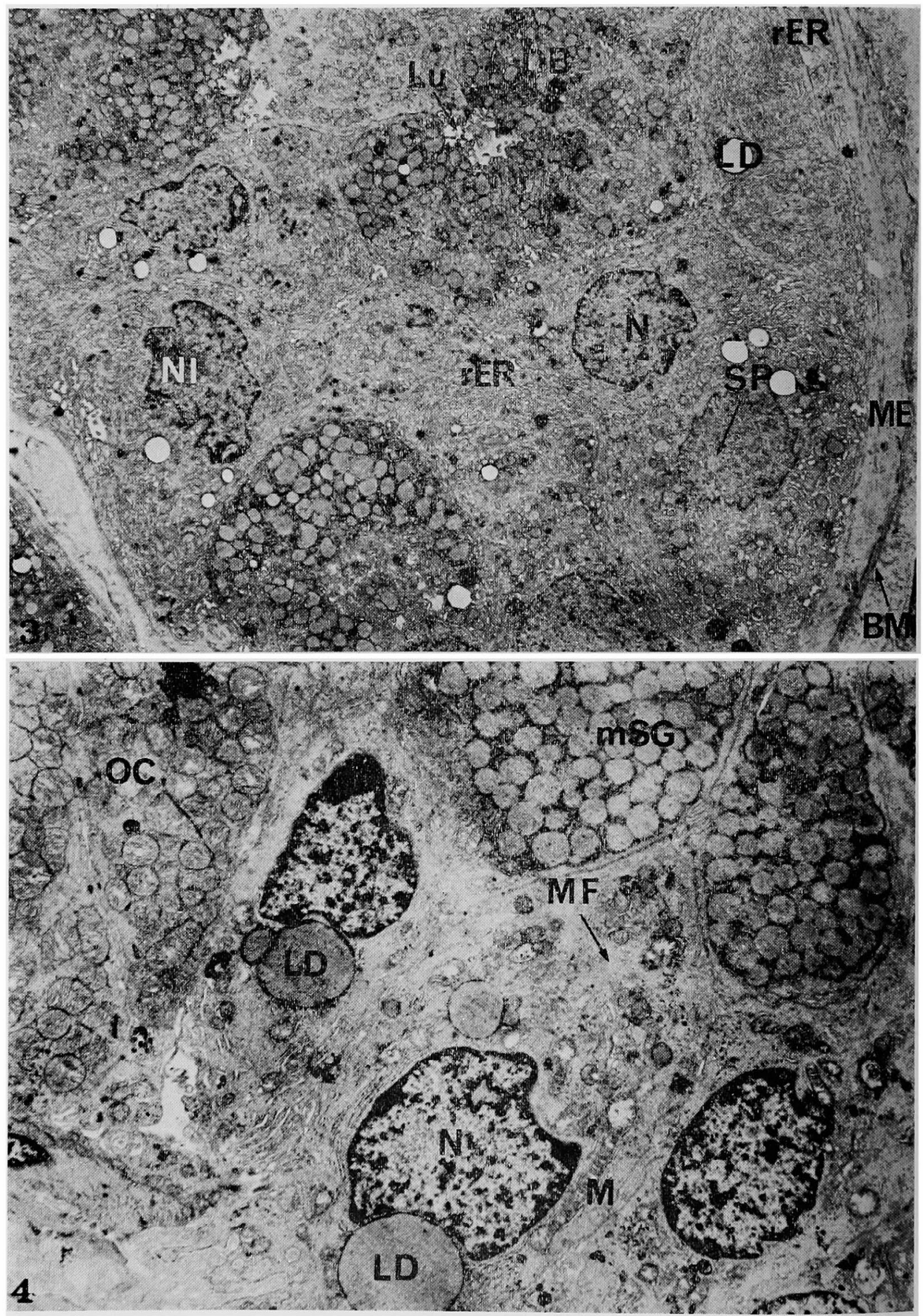
中山諭文附図 (3)

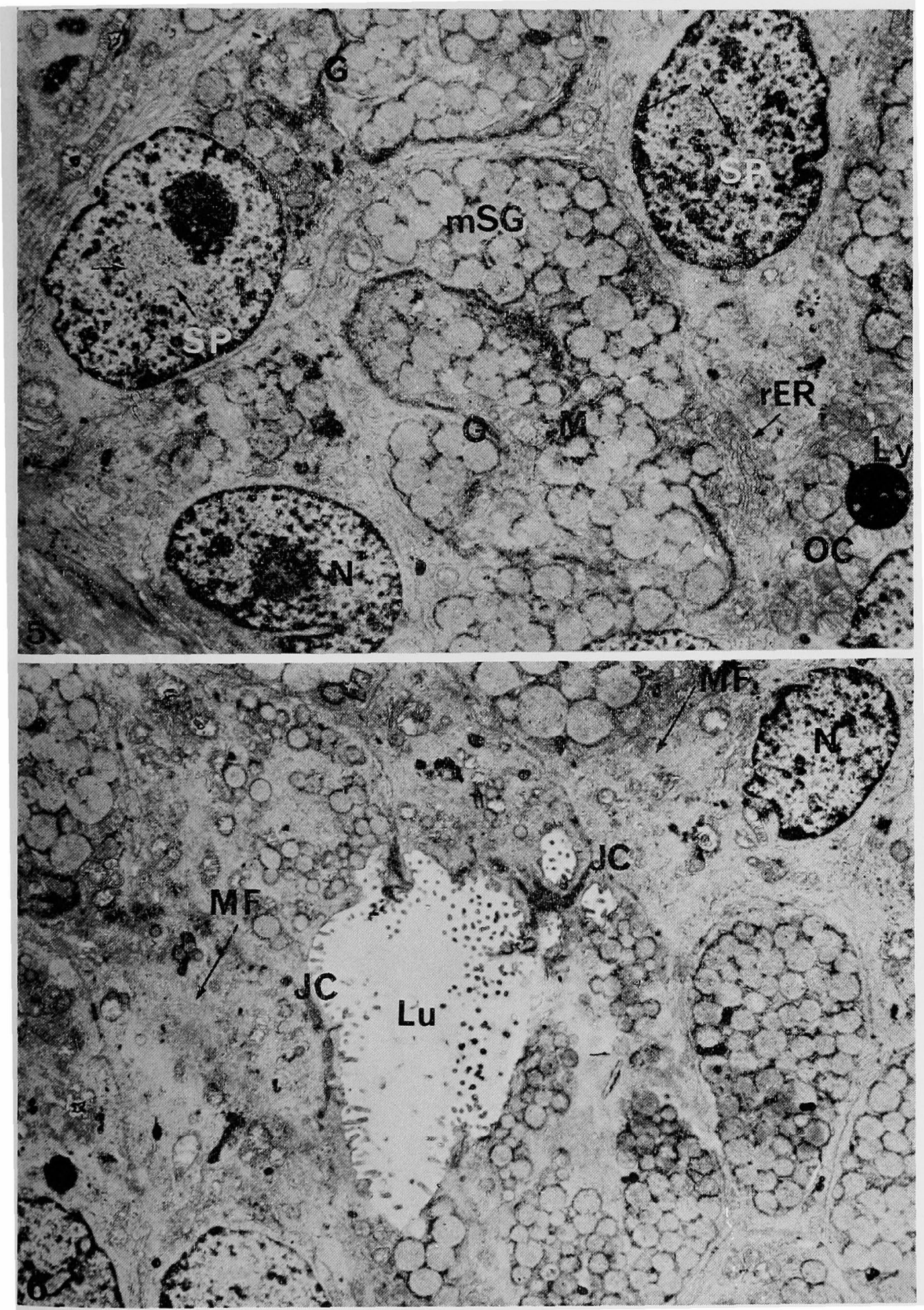


中山論文附図 (4)
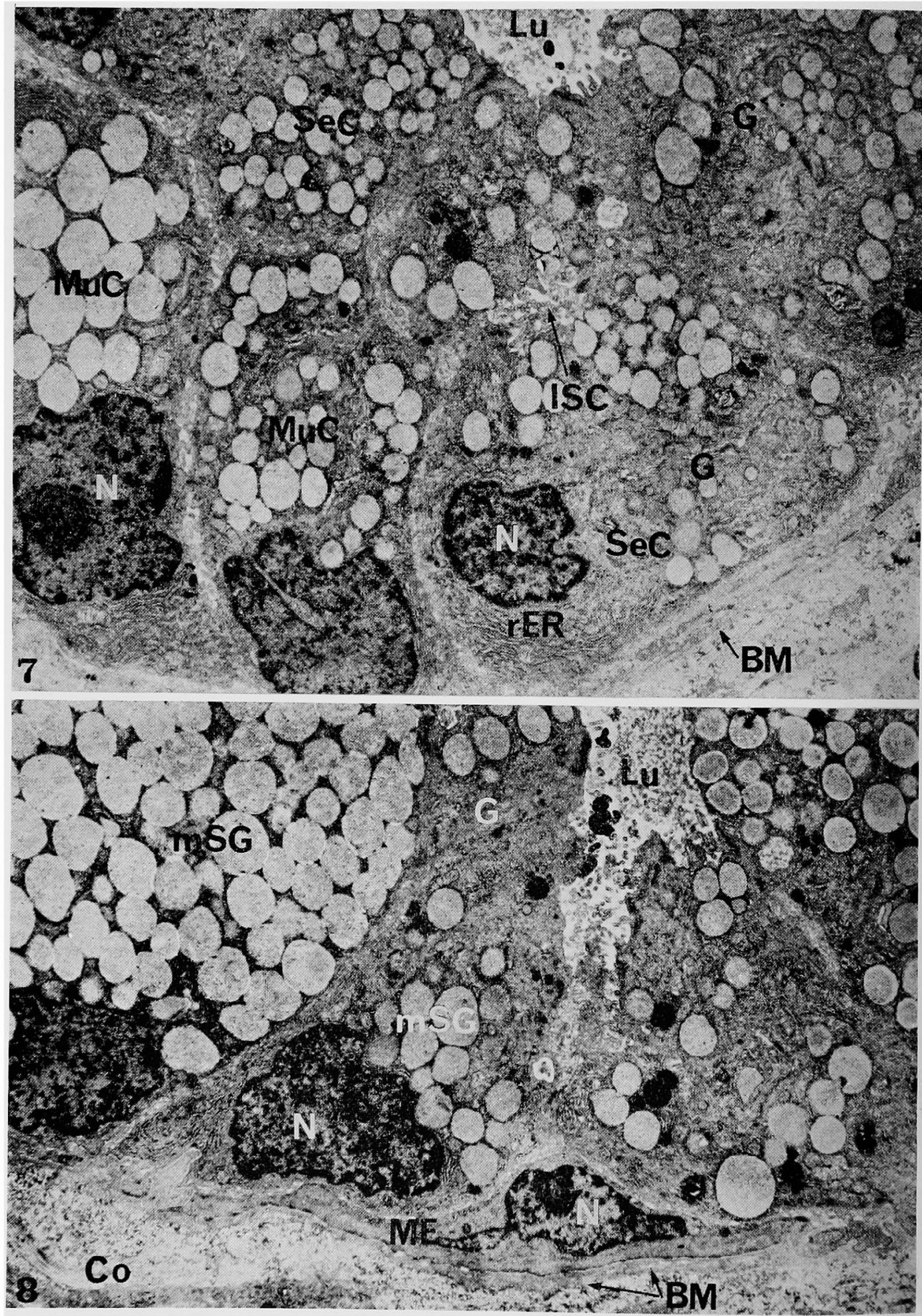


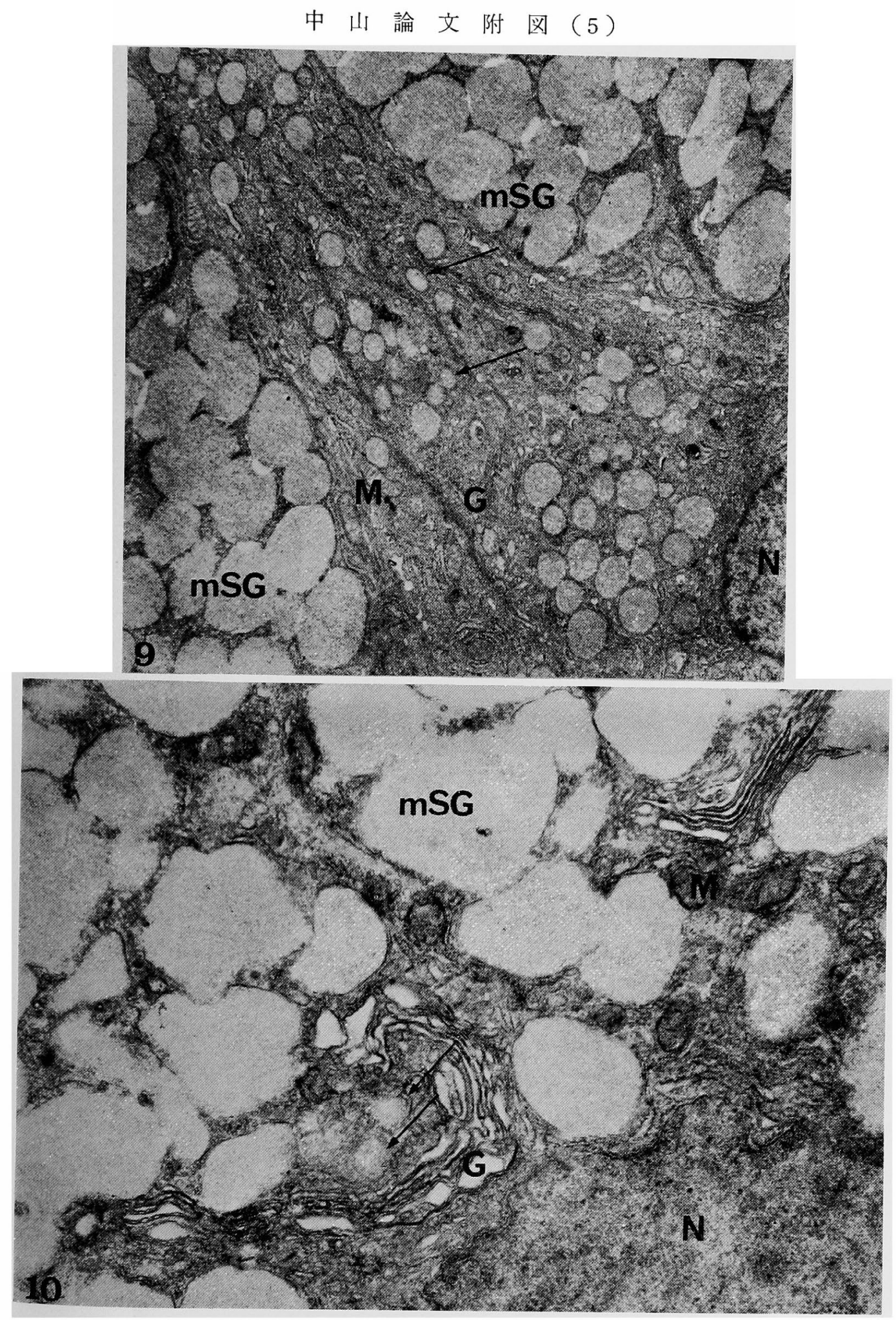


中山論文附図 (6)
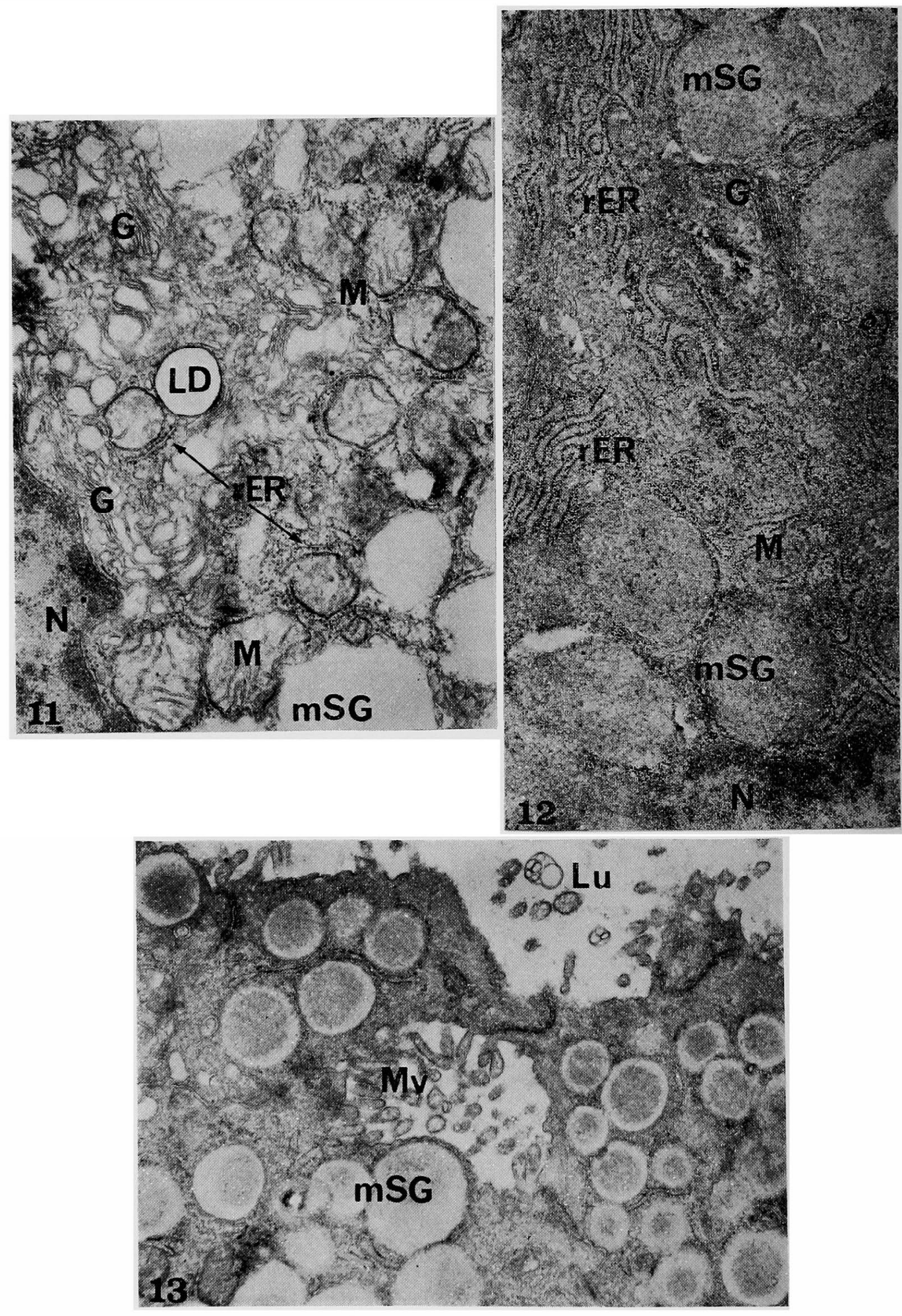
中山論文附図 (7)
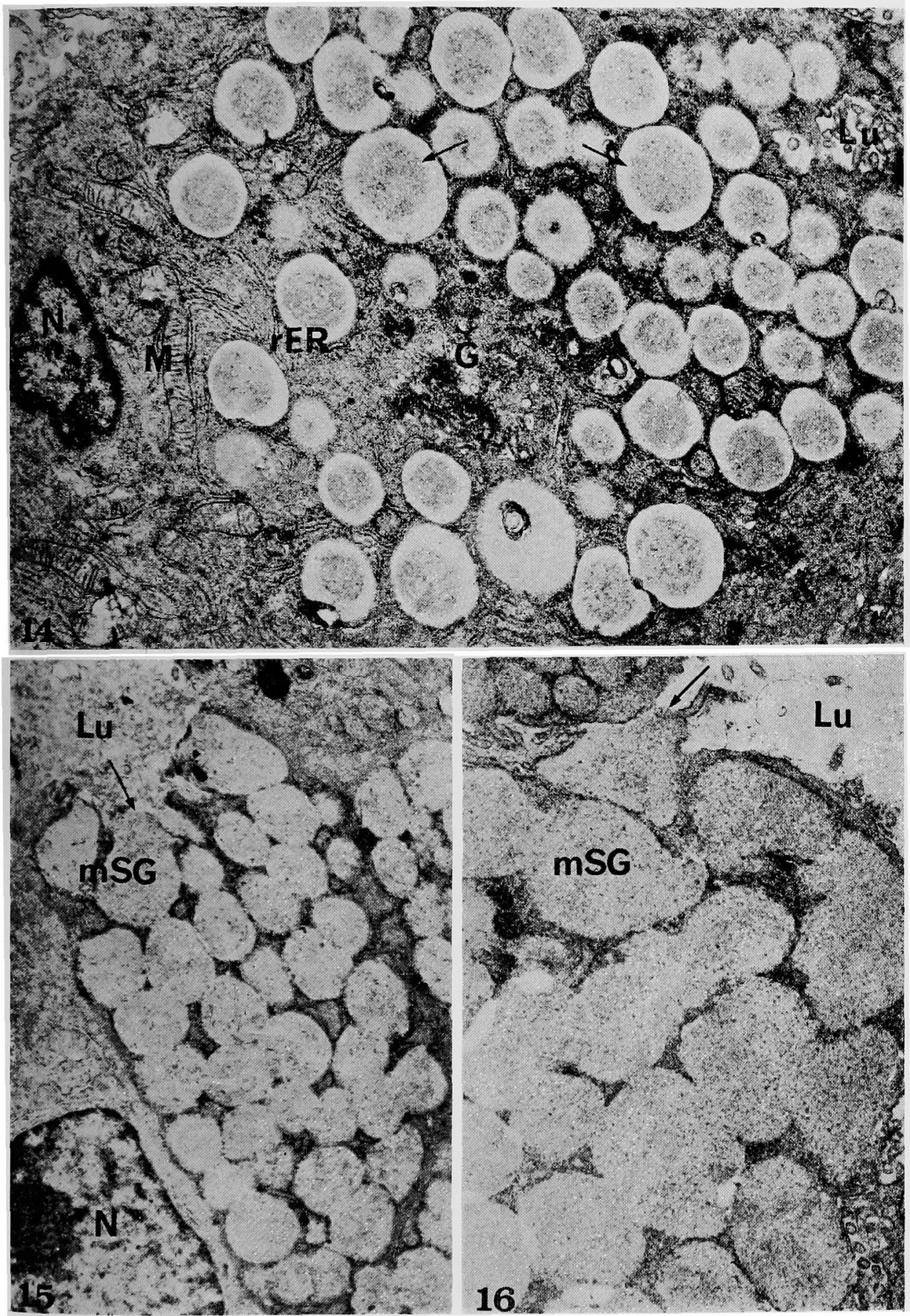
中山論文附図（8）
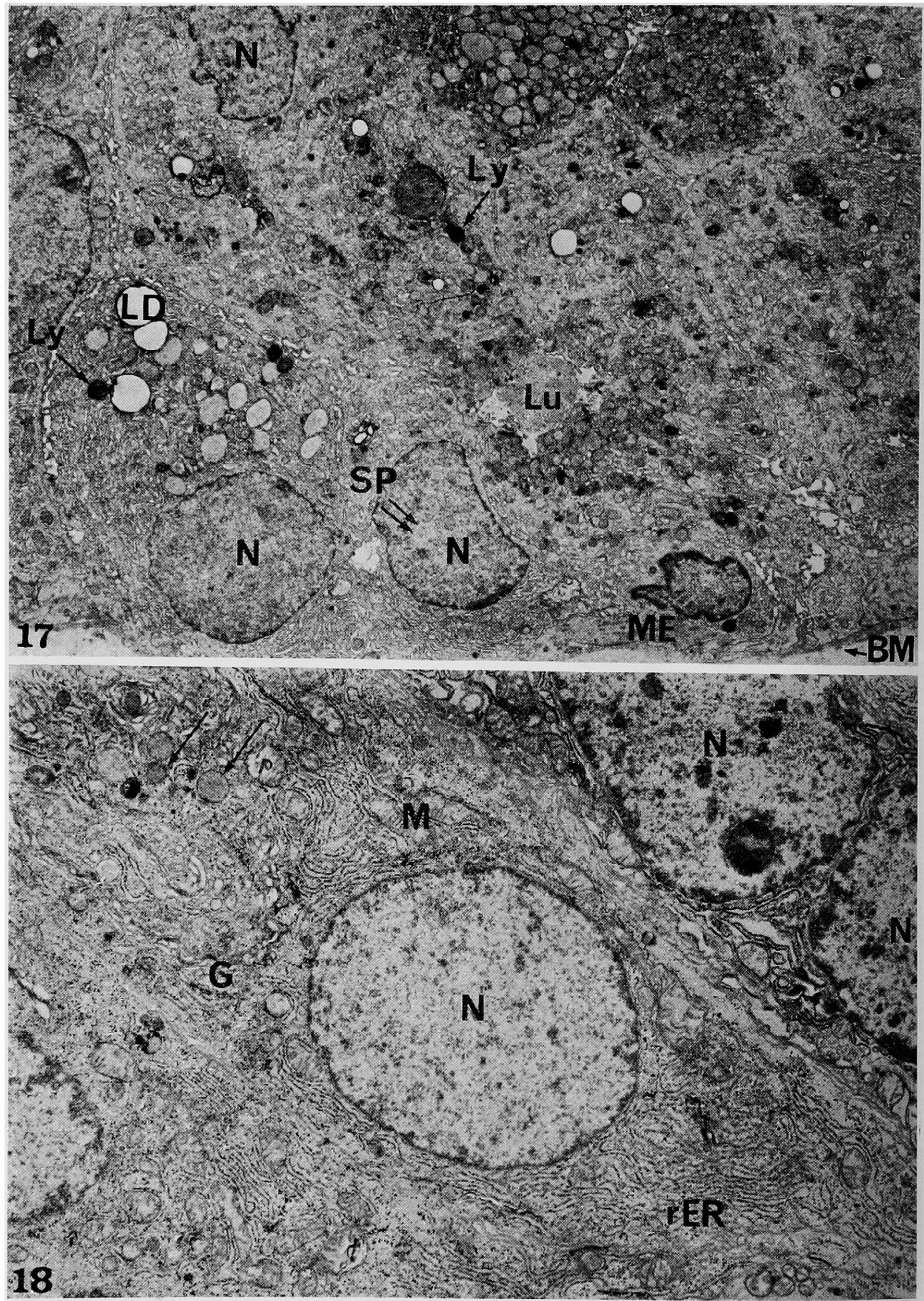
中山論文附図 (9)

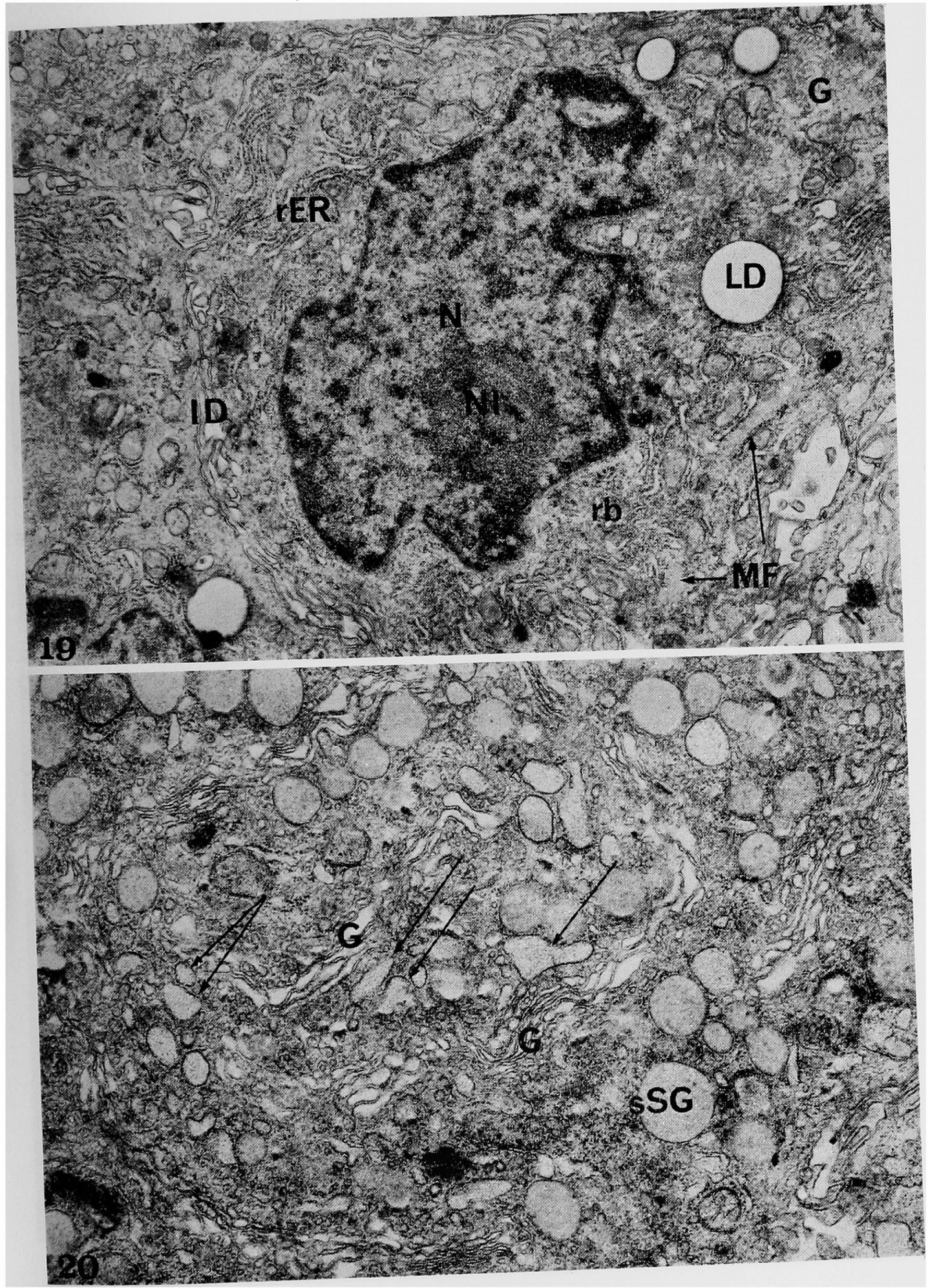


中山論文附図（10）

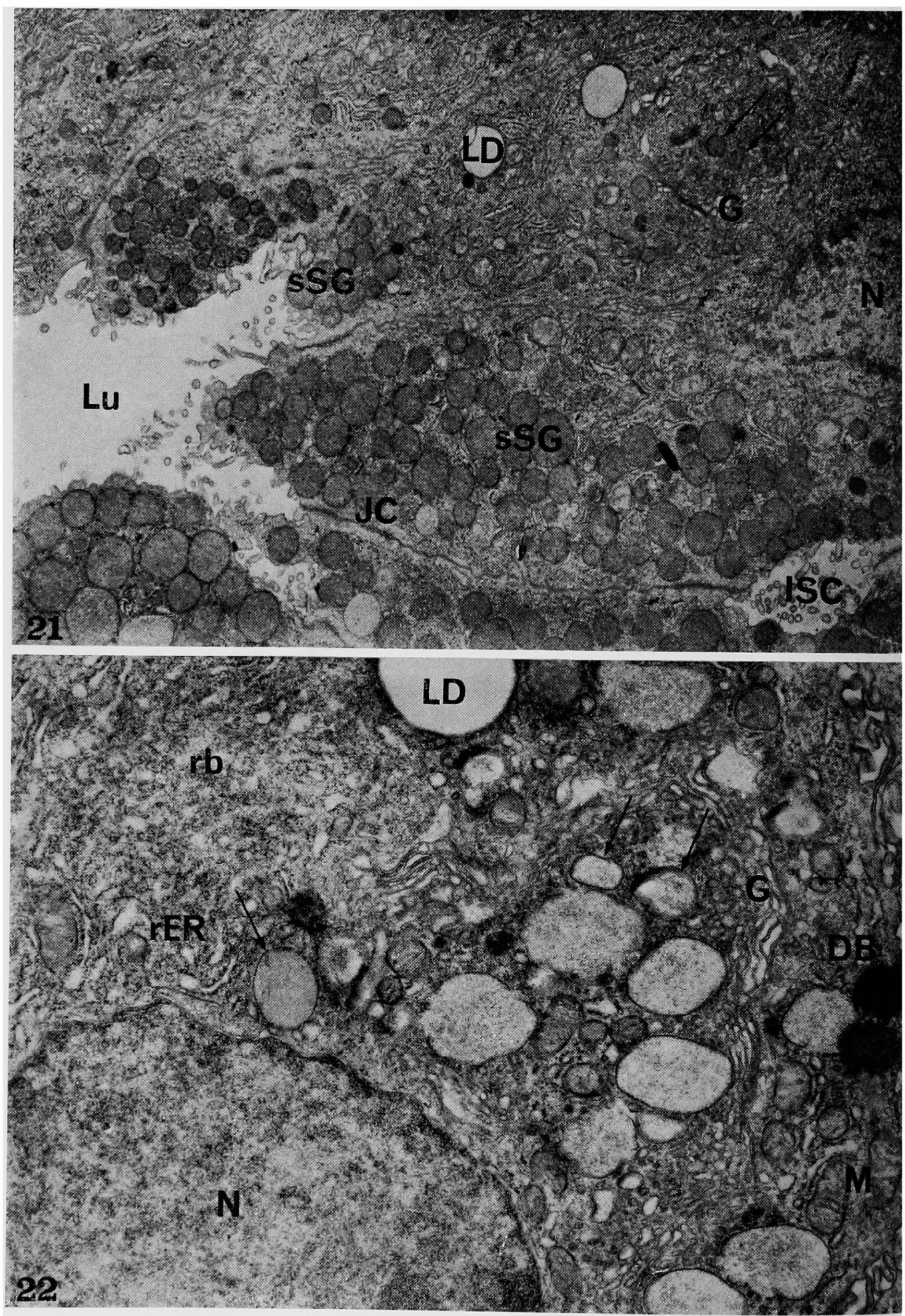


中山論文附図（11）

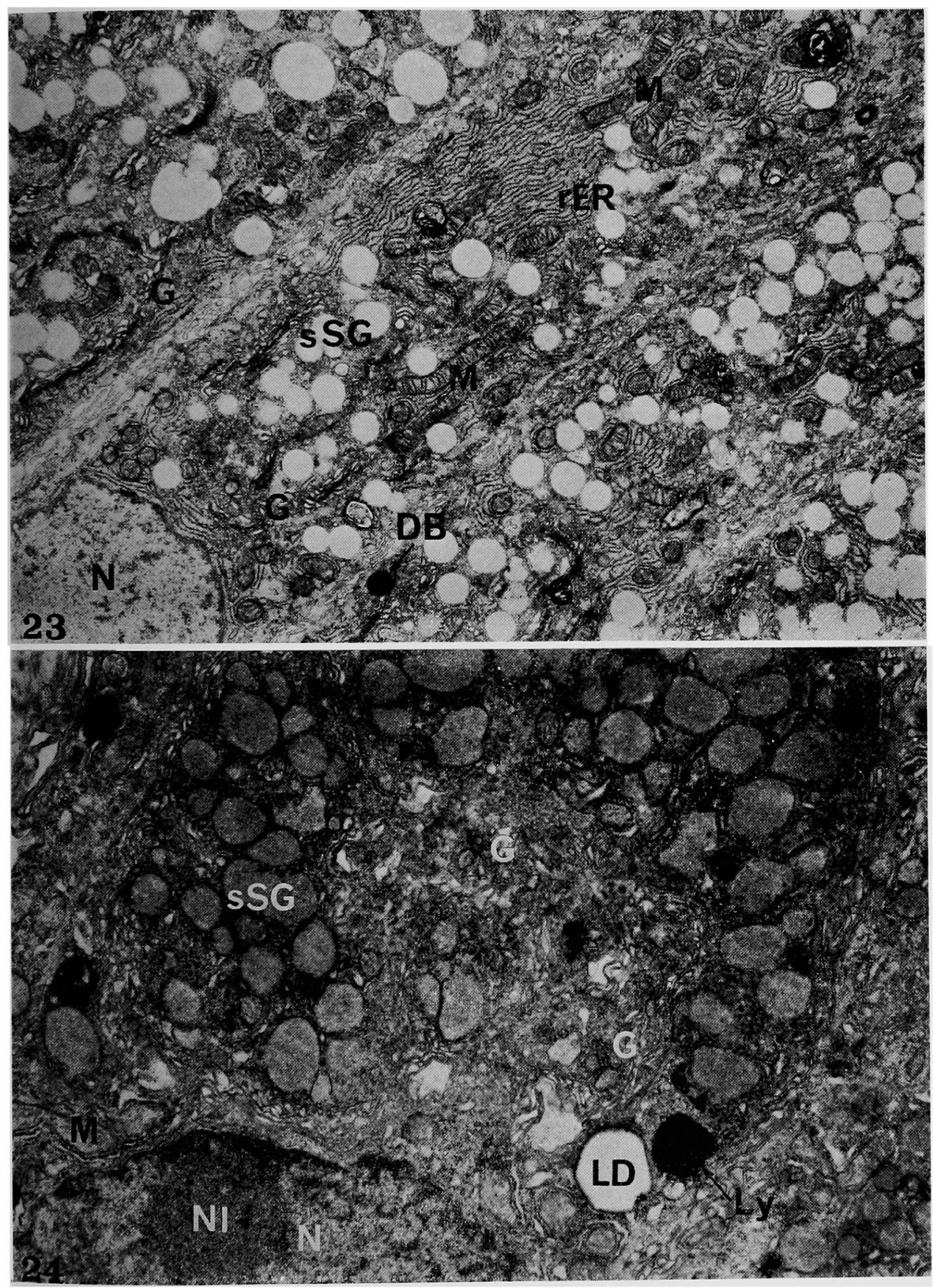


中山論文附図 (12)
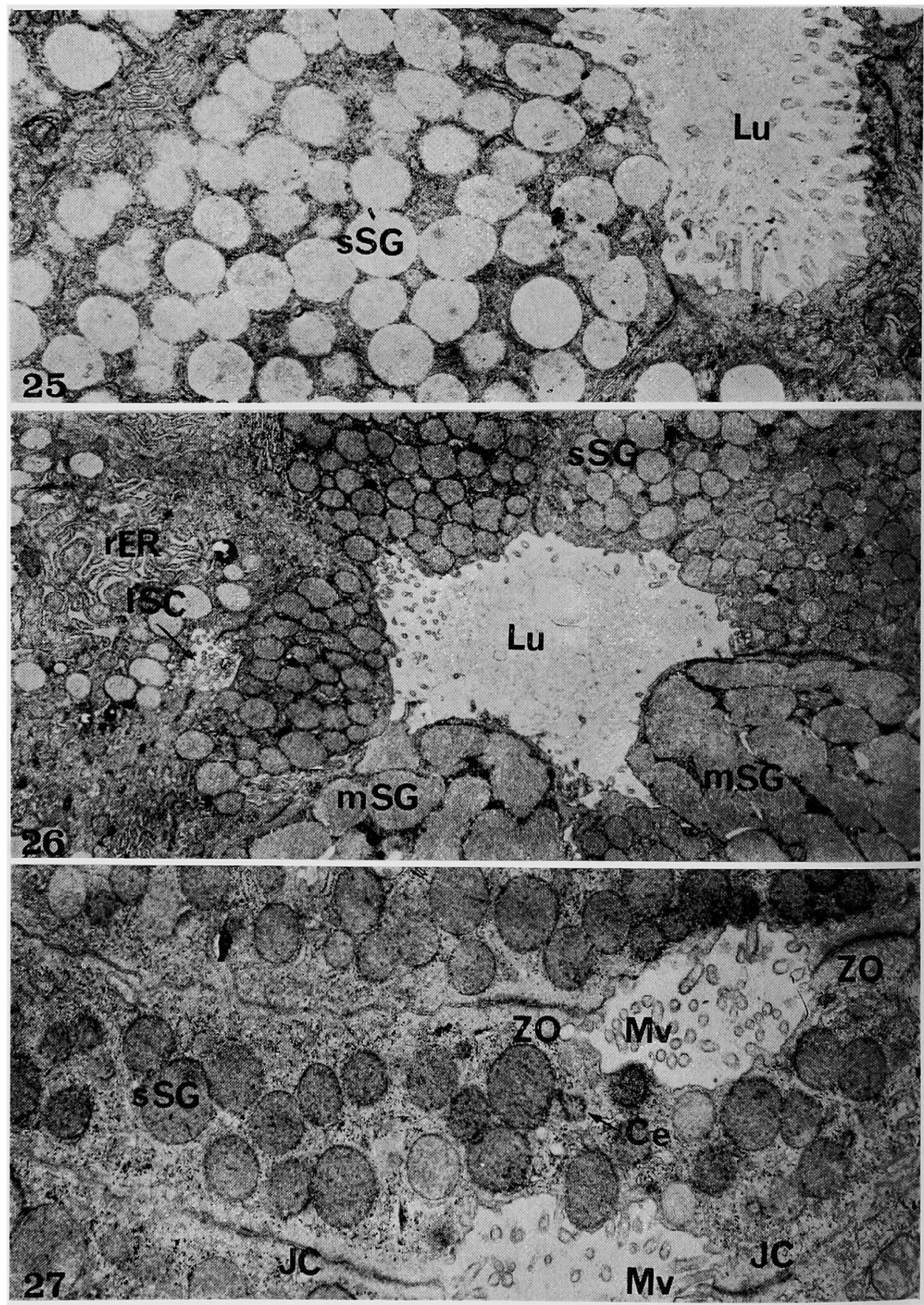
中山論文附図 (13)
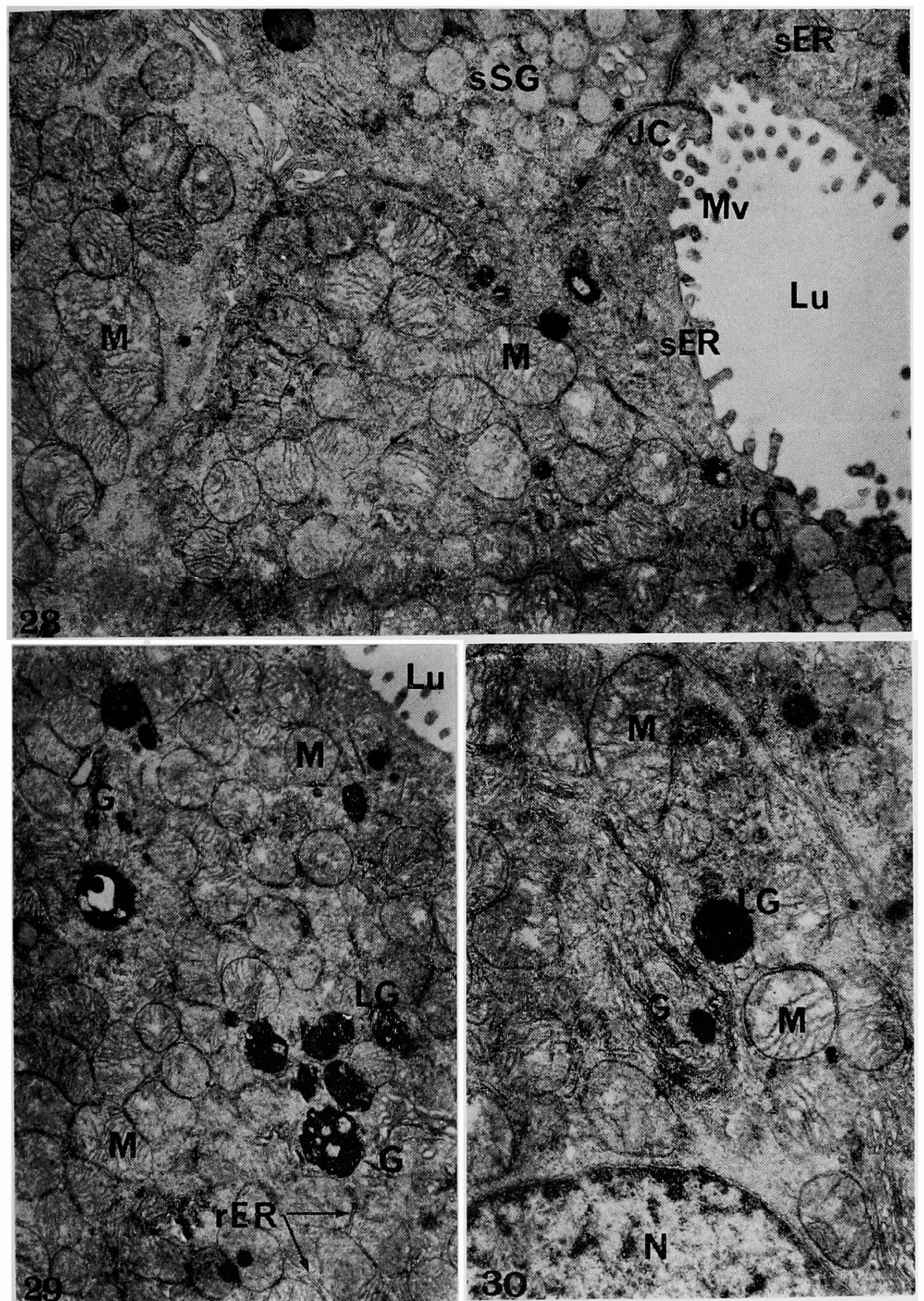
中山論文附図（14）

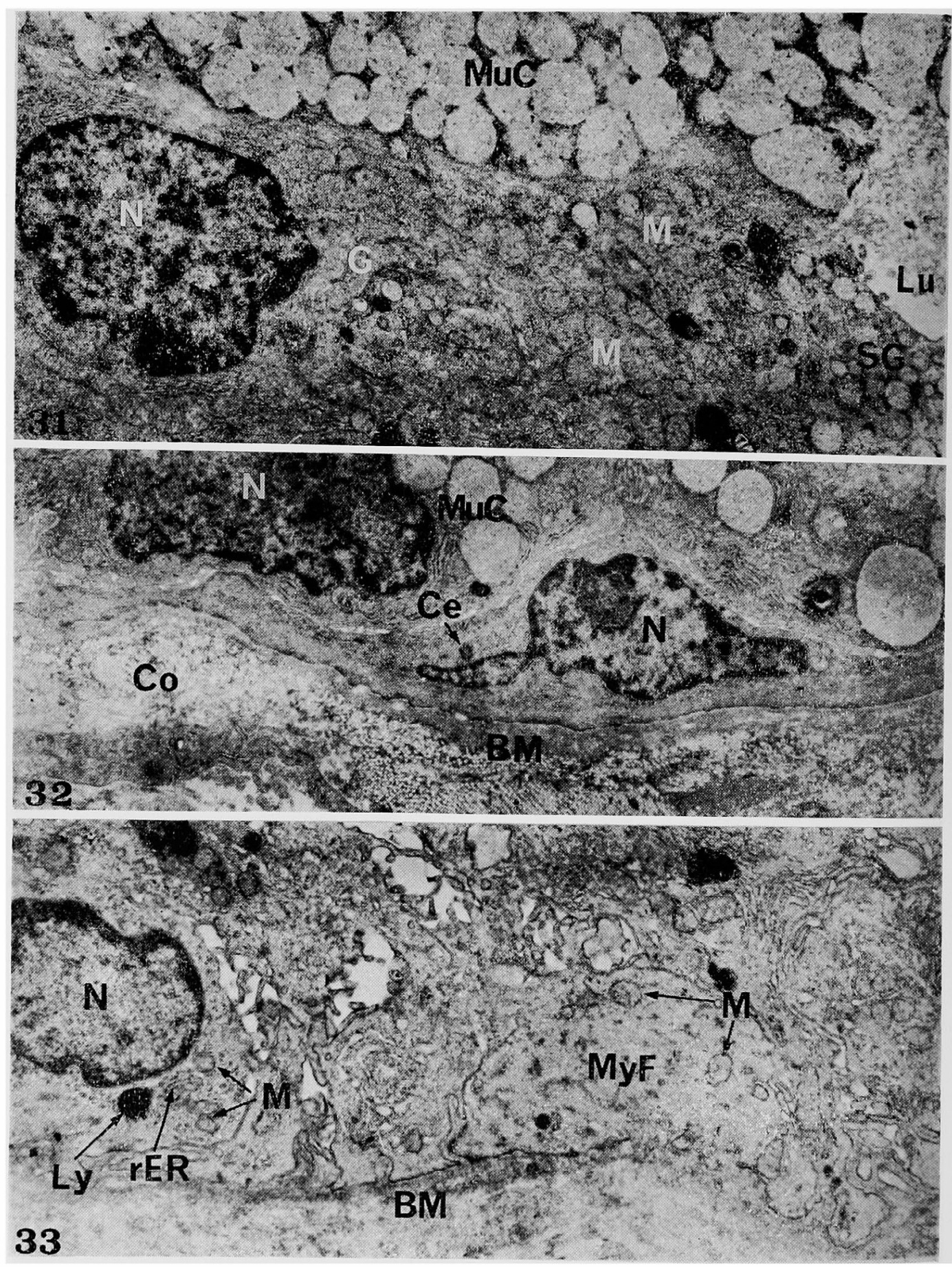


附图 8. 粘液性終末部之解上皮細胞. $\times 8100$

坿图 9. 補充期の粘液細胞核上部，幼若な分泌 顆粘 (1), $\times 8500$

时図10，充盈期の粘液細胞の Golgi 装置。幼若な分 泌顆粒(1)，×16300

附図11. 補充期粘液細胞の核上部、 $\times 22000$

附図12. 補充期の粘液細胞. $\times 15000$

附图13. 補充期の粘液細胞先端部. $\times 17000$

附図14. 充盈期の粘液細胞. 円形の芯(!)， $\times 16000$

附图15. 粘液紏胞の顆粒排出. $\times 11000$

附図16. 粘液細胞の顆粒排出． $\times 15000$

附图17、將液性終末部。 $\times 4700$

附图18. 補充期初期の嶈液細胞. 幼若な分泌顆粒 $(\downarrow)$, $\times 8000$

坿图19. 補充期初期の蔡液細胞. $\times 13000$

附図20，補充期の戚液細胞 Golgi 装䈯。约若な分泌 顆粒 $(\downarrow), \times 15100$

附図21. 将液性終末部．幼若な分泌顆粒 $(\downarrow) ， \times 8300$

附図22. 補充期初期の獎液緗胞. 幼若な分泌顆粒 $(\downarrow)$, $\times 15000$

附图23. 補充期の㢡液細胞。 $\times 8400$

附図24：忘盈期の墏液細胞核上部， $\times 11800$

附图25，冀液細胞の顆粒排出， $\times 12500$

附图26、2種類の細胞でとり囲まれている腺腔， $\times 7500$

附图27，細胞間分泌細管。 $\times 14200$

附图28. mitochondria-rich cell (oncocyte). $\times 11900$

附图29. mitochondria-rich cell (oncocyte) $\times 9800$
附図30. mitochondria-rich cell (oncocyte) の Golgi 装置. $\times 14200$

附図31, 頙粒をもつ mitochondria-rich cell (oncocyte). $\times 15000$

附図32，筋上皮細胞（絴断像）、×12700

附図33．筋上皮細胞（横断像）、×11700

略等説明

$\mathrm{BC}$; 基底細胞, $\mathrm{BM}$; 基底膜, $\mathrm{C}$; 繊毛, $\mathrm{Ce}$; 中心子 $\mathrm{Co} ;$ 結合組織，DB; ライソゾーム様の高密度小体， $\mathrm{G}$; Golgi 装置, ID; 細胞閆嵌合, ISC; 細胞間分泌細管, JC; junctional complex, LD; 脂質滴, LG; リポフスチ ン顆粒, $\mathrm{Lu}$; 腺腔, $\mathrm{Ly}$; ラインゾーム, $\mathrm{M}$; 系粒体, $\mathrm{ME}$; 觔上皮細胞, MF; 微細楾維, $\mathrm{MSG}$; 粘液顆粒, $\mathrm{MuC}$; 粘液細胞, $\mathrm{Mv}$; 微䋐毛, $\mathrm{MyF}$; 筋微原線維, $\mathrm{N}$; 核，N1; 核小体，OC; oncocyte，rb; 自由なリボゾ一 厶, $\mathrm{rER}$; 粗面小胞体, $\mathrm{SC}$; 表層細胞, $\mathrm{SeC}$; 婇液細 胞, sER; 滑面小胞体, SG; 分泌顆粒, SP; spheridion, sSG; 獎液顆粒, ZO; zonula occludens.

な出本誰文の要旨は第26回気管食道科学会総会，第50 回日本解剖学会関東地方会に扔いて発表した。また御指 澊御校閲を賜つた恩師石井英男教授，直接御指尊を頂き ました本学第一解剖学教室柴畸 晋教授に深謝致しま

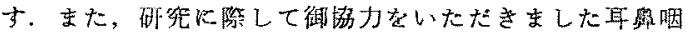

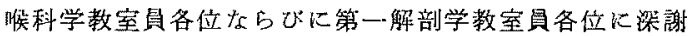
いたします。

（原稿受付 昭和50.11.4 日急載） 